This document was prepared in conjunction with work accomplished under Contract No. DE-AC09-96SR18500 with the U.S. Department of Energy.

This work was prepared under an agreement with and funded by the U.S. Government. Neither the U. S. Government or its employees, nor any of its contractors, subcontractors or their employees, makes any express or implied: 1 . warranty or assumes any legal liability for the accuracy, completeness, or for the use or results of such use of any information, product, or process disclosed; or 2 . representation that such use or results of such use would not infringe privately owned rights; or 3 . endorsement or recommendation of any specifically identified commercial product, process, or service. Any views and opinions of authors expressed in this work do not necessarily state or reflect those of the United States Government, or its contractors, or subcontractors. 
WSRC-MS-2006-00182, Rev. 0

Keywords: waste glass, aging, durability, burial

\section{PERFORMANCE OF A BURIED RADIOACTIVE HIGH LEVEL WASTE (HLW) GLASS AFTER 24 YEARS}

Carol M. Jantzen, Daniel I. Kaplan, Ned E. Bibler, David K. Peeler, and M. John Plodinec

Savannah River National Laboratory

Aiken, SC 29808

For publication only in the Journal of Nuclear Materials, Elsevier Publishing Co.

Editors: L.K. Mansur (Chairman), Metals and Ceramics Division, Oak Ridge National Laboratory, P.O. Box 2008, Oak Ridge, TN 37831-6138, USA, (Email:mansurlk@ornl.gov)

L.O. Werme, Swedish Nuclear Fuel and Waste Management Co., Box 5864, S-10248 Stockholm, Sweden, (Email:skblw@skb.se). 


\title{
PERFORMANCE OF A BURIED RADIOACTIVE HIGH LEVEL WASTE (HLW) GLASS AFTER 24 YEARS
}

\author{
Carol M. Jantzen*, Daniel I. Kaplan, Ned E. Bibler, David K. Peeler, \\ and M. John Plodinec \\ Savannah River National Laboratory \\ Aiken, SC 29808
}

\begin{abstract}
A radioactive high level waste glass was made in 1980 with Savannah River Site (SRS) Tank 15 waste. This glass was buried in the SRS burial ground for 24 years but lysimeter data was only available for the first 8 years. The glass was exhumed and analyzed in 2004 . The glass was predicted to be very durable and laboratory tests confirmed the durability response. The laboratory results indicated that the glass was very durable as did analysis of the lysimeter data. Scanning electron microscopy of the glass burial surface showed no significant glass alteration consistent with the results of the laboratory and field tests. No detectable $\mathrm{Pu}, \mathrm{Am}, \mathrm{Cm}, \mathrm{Np}$, or $\mathrm{Ru}$ leached from the glass into the surrounding sediment. Leaching of $\beta / \delta$ from ${ }^{90} \mathrm{Sr}$ and ${ }^{137} \mathrm{Cs}$ in the glass was diffusion controlled. Less than $0.5 \%$ of the Cs and $\mathrm{Sr}$ in the glass leached into the surrounding sediment, with $>99 \%$ of the leached radionuclides remaining within 8 centimeters of the glass pellet.
\end{abstract}

\section{Introduction}

The most important requirement for high-level waste (HLW) glass acceptance for disposal in a geological repository is the chemical durability. During the early stages of glass dissolution in a geological repository, near static conditions are expected to dominate. Under these conditions, a gel layer resembling a membrane forms on the glass surface through which ions exchange between the glass and the contacting groundwater. The hydrated gel layer exhibits acid/base properties which are manifested as the $\mathrm{pH}$ dependence of the thickness and nature of the gel layer. The gel layer has been determined to age into either clay mineral assemblages or zeolite mineral assemblages [1]. The formation of one phase preferentially over the other has been experimentally related to changes in the $\mathrm{pH}$ of the contacting solution and related to the relative amounts of $\mathrm{Al}^{+3}$ and $\mathrm{Fe}^{+3}$ in a waste glass. During laboratory studies the formation of clay mineral assemblages on the leached glass surface layers (lower $\mathrm{pH}$ environments and/or $\mathrm{Fe}^{+3}$ rich waste glasses) causes the dissolution rate to slow to a long term "steady state" rate.[1] The formation of zeolite mineral assemblages of the analcime type (higher $\mathrm{pH}$ environments and/or $\mathrm{Al}^{+3}$ rich glasses) on leached glass surface layers causes the dissolution rate to increase and return to the initial high forward rate [1,2,3].

\footnotetext{
* Corresponding author. Tel: 803-725-2374; fax: 803-725-4704.

E-mail address: carol.jantzen@srnl.doe.gov
} 
The return to the forward dissolution rate is undesirable for long term performance of glass in a disposal environment. The return to the forward rate of dissolution raises additional questions about (1) how short term accelerated laboratory performance tests relate to long term performance in a disposal environment and (2) whether the forward rate of dissolution or the steady state rate of dissolution should be used for repository risk assessments.

The study of HLW glasses that have been buried for long periods of time in a disposal environment and/or natural analog studies are the only ways to elucidate whether short term accelerated laboratory durability test performance and glass durability models are related to the long term durability and performance of a waste glass in a disposal environment. The nature of the leached layer formed, the overall glass dissolution, and the migration of both radioactive and non-radioactive species into the surrounding soil must all be assessed.

\subsection{Field Tests of Simulated and Alpha-Doped HLW Glasses}

Many field tests of simulated (non-radioactive) HLW glass durability have been performed and reviews of the subject are available elsewhere $[4,5,6]$. In the nonradioactive field tests in natural groundwaters, the glasses proved to be as durable and/or more durable than indicated during accelerated laboratory testing [4,5].

Tests have been performed on non-radioactive simulated glasses and/or glasses doped with alpha emitting radionuclides such as ${ }^{134} \mathrm{Cs},{ }^{90} \mathrm{Sr}$, and ${ }^{239} \mathrm{Pu}$. These glasses were subjected to a 5 year burial in the Boom clay at Mol, Belgium at temperatures of $16^{\circ} \mathrm{C}$, $90^{\circ} \mathrm{C}$, and $170^{\circ} \mathrm{C}$ for periods of 2 to 7.5 years. Subsequent experiments were performed with four glasses doped with alpha emitting ${ }^{238-242} \mathrm{PuO}_{2},{ }^{237} \mathrm{NpO}_{2}$, and/or ${ }^{241} \mathrm{Am}_{2} \mathrm{O}_{3}$ $[7,8,9,10]$. These glasses were simultaneously subjected to gamma fields during burial at $90^{\circ} \mathrm{C}$ for 5 years. In the case of the alpha emitting radionuclides in the gamma irradiation fields, the durability of the glass was similar to that of accelerated laboratory testing [10].

The leached layers of the glasses buried in Boom clay were examined by scanning electron microscopy coupled with electron diffraction. The SON68 (R7T7) French glass had a leached layer of $\sim 200 \mu \mathrm{m}$ that was enriched at the top in $\mathrm{Al}$ and $\mathrm{Si}$ and reduced in $\mathrm{Ca}$ and $\mathrm{Na}$. Enrichment in $\mathrm{K}$ and $\mathrm{Mg}$ was attributed to sorption from the Boom clay. On top of the leached layer were precipitates enriched in $\mathrm{Al}, \mathrm{Si}, \mathrm{Mg}, \mathrm{Fe}$, and $\mathrm{K}$. In-between the leached layer and the precipitates was a region depleted in $\mathrm{Si}, \mathrm{Al}$, and $\mathrm{Ca}$. The Belgian glass SM513 (PAMELA) had a $350 \mu \mathrm{m}$ leached layer enriched in $\mathrm{Ti}$ and $\mathrm{Al}$ and reduced in $\mathrm{Na}, \mathrm{Ca}$, and $\mathrm{Mg}$. Again $\mathrm{K}$ was enriched in the layer and attributed to be from the burial medium, the Boom clay. Glass SM527 (PAMELA) had no reaction layer but a thin precipitate layer enriched in K, Mg, Si, and Al. Lastly, Glass WG124 (a silicate glass) had a 500-600 $\mu \mathrm{m}$ layer with a double structure. The outer layer was enriched in $\mathrm{Fe}, \mathrm{Al}, \mathrm{Mg}$ and depleted in $\mathrm{Si}, \mathrm{Ca}, \mathrm{Na}$, and $\mathrm{K}$ while the inner layer was depleted in $\mathrm{Mg}$, $\mathrm{Si}, \mathrm{Ca}$, and $\mathrm{Na}$. Precipitates enriched in Si, Al, Mg, Fe, K and S were found on the outermost surface [7].

The Boom clay burial glass with the least reaction layer was the SM527 glass which 
was the glass highest in $\mathrm{Al}_{2} \mathrm{O}_{3}$ content, e.g. $19.96 \mathrm{wt} \%$ compared to $\mathrm{Al}_{2} \mathrm{O}_{3}$ contents of 2.94.91 for the three other glasses buried. The study concluded that the three lower $\mathrm{Al}_{2} \mathrm{O}_{3}$ containing glasses dissolved via a combination of network dissolution, selective leaching and ion exchange. The high $\mathrm{Al}_{2} \mathrm{O}_{3}$ containing glass was determined to leach by a congruent mechanism and only a minor contribution from a selective leaching mechanism.

In some tests the presence of the Boom Clay and ground frit as backfill materials were found to act as silica sources and decrease the glass alteration by two orders of magnitude. The silica rich clay and the silica rich frit provided silica saturated aqueous environments for the glass which inhibited leaching [10]. The glass alteration layer thickness was also found to increase with increasing $\alpha \beta \gamma$-activity of the glass [9].

\subsection{Field Tests of HLW Radioactive Glasses}

To date there are only two documented HLW glass burial experiments in shallow land disposal sites where lysimeter measurements of radionuclide migration were simultaneously monitored. A third burial study is the focus of this publication.

\subsubsection{Chalk River Nuclear Laboratories (CRNL) Field Tests}

The first and oldest shallow land disposal tests were those at the Chalk River Nuclear Laboratories (CRNL) in Ontario, Canada [11,12,13,14]. The waste being immobilized was a $\mathrm{HLW} \mathrm{UO}_{2}$ fuel recycle waste and the major radionuclides were ${ }^{242} \mathrm{Pu}$ and ${ }^{238} \mathrm{U}$ but the activity was primarily generated by ${ }^{137} \mathrm{Cs}$ and ${ }^{90} \mathrm{Sr}$. Two sets of glass blocks based on ground nepheline syenite rock with $15 \% \mathrm{CaO}$ were buried without secondary containers, one in 1959 and one in 1960. The compositions of these two sets of glasses were calculated from the data in Reference 14 and are given in Table I.

The glasses were exhumed in 1978 and the chemistry and surfaces of the glass examined. Laboratory measurements were made on the rates of corrosion of the glass and coupled with field measurements of the rates of ${ }^{137} \mathrm{Cs}$ and ${ }^{90} \mathrm{Sr}$ migration from the glass after shallow burial for $\sim 18-19$ years. The ${ }^{90} \mathrm{Sr}$ and ${ }^{137} \mathrm{Cs}$ migration from the field study were slower than those measured in the accelerated laboratory tests and this difference was attributed to the lower temperature in the field as compared to the laboratory. In addition, the ${ }^{90} \mathrm{Sr}$ was found to have sorbed onto iron oxyhydroxides in the surrounding soil so that migration of this radionuclide was retarded.

Depth profiling of the glass block surface with Secondary Ion Mass Spectroscopy (SIMS) showed that $\mathrm{Ca}, \mathrm{Na}, \mathrm{Cr}$, and Fe were depleted down to a depth of 70-80 nm (0.07$0.08 \mu \mathrm{m}$ ) of the surface while Si, Mg, and Th were enriched in the surface layers [14]. Thorium was enriched to a depth of $\sim 100 \mathrm{~nm}(0.1 \mu \mathrm{m})$ as was $\mathrm{U}$ but Fe and Mg were only enriched to a depth of $\sim 45 \mathrm{~nm}(0.045 \mu \mathrm{m})$. Since the glass contained little $\mathrm{Mg}$, the $\mathrm{Mg}$ enrichment was thought to be a magnesium silicate that had formed from the silica in the glass and the $\mathrm{Mg}$ in the groundwater. The thickness of the material removed during the 20 year burial test was estimated from the Th enrichment and corresponded to a $400 \mathrm{~nm}(0.4$ $\mu \mathrm{m})$ loss from the original glass surface. The leached layer was found to contain a "fixed" 
ferromagnesian fraction which sorbed $13-14 \%$ of the ${ }^{90} \operatorname{Sr}[13]$. Measurement of the radionuclides in the surrounding soil indicated that the leaching rates were two orders of magnitude lower than that predicted from laboratory leaching tests [15].

\subsubsection{Nuclear Power Plant (NPP) Intermediate Level Waste Field Tests}

In 1987 blocks of K26 glass used to immobilize intermediate level nuclear power plant (NPP) waste from the Kursk (RBMK) reactor in Russia were buried in a loamy soil [16]. The glass was poured into carbon steel rectangular containers that did not have lids. The glass containers without lids were buried in a steel tray that was supplied with a water trap and a tube for water extraction by pumping. The tray was deeper than the pour containers and the tray was filled with pure sand before the rest of the burial trench was backfilled with the loamy soil [17]. While the conditions are considered saturated the glass was not in direct contact with the loamy soil.

Waste glass with $35 \mathrm{wt} \%$ waste oxides was produced [18]. The K26 glass is a high sodium containing borosilicate glass made from a waste containing $86 \mathrm{wt} \% \mathrm{NaNO}_{3}[16,18]$ and the prime contaminants were ${ }^{137} \mathrm{Cs}(82 \%),{ }^{134} \mathrm{Cs}$, and ${ }^{90} \mathrm{Sr}$. Both saturated groundwater and non saturated groundwater conditions were studied $[19,20]$. The blocks buried under unsaturated conditions were examined after 8 years burial [21] and the leached layer was determined to be 2-6 $\mu \mathrm{m}$ by Scanning Electron Microscopy (SEM). The blocks buried under saturated conditions were extensively studied after 12 years of burial $[19,22]$. In 2001, X-ray analysis and SEM of the surface of the glass buried under saturated conditions showed no evidence for the formation of secondary alteration phases on the glass surface [19]. Reanalysis in 2004 [22] identified some small crystalline inclusions of quartz $\left(\mathrm{SiO}_{2}\right)$, calcite $\left(\mathrm{CaCO}_{3}\right)$, hematite $\left(\mathrm{Fe}_{2} \mathrm{O}_{3}\right)$ and anatase/rutile $\left(\mathrm{TiO}_{2}\right)$ although the layer was primarily amorphous. About $1.3 \mathrm{E}-03$ percent of the radioactivity had leached into the groundwater during the 12 year period, mainly ${ }^{137} \mathrm{Cs}$.

\subsubsection{Savannah River National Laboratory (SRNL) Field Tests}

Details of the third HLW glass burial are given in this study. A radioactive Savannah River Site (SRS) HLW waste glass was buried in a lysimeter located $\sim 11 \mathrm{~m}$ above the water table. As such the glass was exposed to saturated and unsaturated conditions as controlled by local rainfall and weather conditions. The glass was left in the field lysimeter for 15 years before it was recovered by coring. The core sample was left in a $16{ }^{\circ} \mathrm{C}$ cooler for another nine years, leaving the glass in contact with moist sediment for 24 years. The overall glass composition was analyzed after the glass was exhumed. The formation of a leached layer and the glass/soil contact zone was studied by scanning electron microscopy (SEM).

The SRS burial glass composition was used to assess the glass durability in two ways. First, the glass composition was analyzed and the composition used to predict the glass durability using the SRS model that has been used to operate the SRS vitrification facility for $~ 15$ years (the Thermodynamic Hydration Energy MOdel, THERMO ${ }^{\mathrm{TM}}$ ) [23,24,25]. The THERMO ${ }^{\mathrm{TM}}$ model is based on a short term accelerated 7-day durability test, ASTM 
C1285 [26]. The durability of the burial glass was measured using the same accelerated glass durability test. The short term durability of the burial glass was then related to the long term durability with respect to the leached layer using the recently developed Activated Complex Theory (ACT ${ }^{\mathrm{TM}}$ ) [27] and the glass composition.

\section{Stages of Glass Dissolution}

Current theories of glass dissolution suggest that all glasses typically undergo an initial rapid rate of dissolution known as the forward rate. However, as the contact time between the glass and the leachant lengthens some glasses come to pseudo-equilibrium and leach at a "steady state" rate while other glasses undergo a disequilibrium reaction with the leachant solution that causes a sudden change in the solution $\mathrm{pH}$ or the silica activity in solution [1]. The return to the forward rate after achieving steady state is undesirable as it causes the glass to return to the rapid dissolution characteristic of initial dissolution. The initial rate is known as Stage I dissolution, the steady state rate is known as Stage II dissolution, and the return to the forward rate is known as Stage III dissolution. Stage I and Stage II dissolution are normally controlled by diffusion and follow a mathematical function related to the square root of the test duration.

\subsection{Stage I Dissolution (Forward Rate)}

Typically during the glass dissolution process in near static conditions, there is a short period of alkali proton-hydronium ion-exchange followed by matrix dissolution and/or solution precipitation/condensation reactions [28,29]. This initial rapid rate of ionexchange is commonly known as the forward rate (Stage I) of glass dissolution (Figure 1).

\subsection{Stage II Dissolution (Steady State Rate)}

The forward glass dissolution rate is modified by a rate-limiting mechanism hypothesized to be related to the activated complexes being formed that become components of the gel layer or activated complexes in solution. Thus the gel layer is composed of hydrated silica, alumina, and ferria and other large, highly charged cations (high $\mathrm{Z} / \mathrm{r}$ ratio cations where $\mathrm{Z}$ is the atomic charge and $\mathrm{r}$ is the atomic radius). The glass reaction zone is defined as the leached layer solution interface where equilibrium is considered to be between the glass surface sites and the ions in solution [30]. The top of the gel reaction zone represents the leached layer glass interface where a counter-ion exchange occurs [30] that can form secondary precipitates, e.g. metal hydroxo and/or metal silicate complexes that have reached saturation in the leachate often precipitate on the surface of the gel layer [28, 29, 31, 32, 33, 34]. The gel layer may, under certain conditions, act as either or both a selective membrane $[31,35]$ or as a protective/passivating layer [28, 29, 33, 34, 36, 37, 38, 39, 40]. The slowing of the glass dissolution to a steady state rate by any combination of the above mechanisms is referred to as Stage II or steady state dissolution (Figure 1). The leached layer is generally a $\mathrm{Fe}^{+3}$ rich phase such as the clay mineral nontronite (see Section 2.4). 


\subsection{Stage III Dissolution (Return to the Forward Rate)}

Glass dissolution has been accelerated in static laboratory scale tests by increasing the glass surface area (SA) exposed to a given volume of leachant (V), e.g. performing crushed glass tests, and/or by extending the test duration ( $\mathrm{t}$ in days) to long times, and/or by increasing the test temperature $(\mathrm{T})$. Testing can be accelerated in monolithic glass laboratory scale tests by increasing the test temperature, increasing the test duration, and/or by using steam. Based on the early experiments on window glass [41] in saturated steam $\left(150-200^{\circ} \mathrm{C}\right)$, the higher the temperature and the more saturated the steam, the greater the penetration of the $\mathrm{H}_{2} \mathrm{O}$ and $\mathrm{OH}^{-}$into the glass and the more rapidly an altered gel layer is formed. Much progress has been made in the accelerated durability testing of nuclear waste glasses using the Vapor Hydration Test (VHT) [42]. In VHT testing a nominal temperature of $200^{\circ} \mathrm{C}$ is used and exposure of the glass to steam causes a high effective $\mathrm{SA} / \mathrm{V}[42,43]$.

Studies have shown [44] that glass durability test acceleration using the (SA/V)•time parameter is only valid up to values of $\sim 20,000 \mathrm{~m}^{-1}$, at which point there is a possible change in mechanism for some glasses. There is evidence from poorly durable glasses that at 20,000 $\mathrm{m}^{-1}$ that all of the glass has been completely reacted [45]. This change in mechanism causes the long term dissolution rate to reaccelerate at the initial forward dissolution rate for some glasses. This unexpected, and poorly understood, return to the forward dissolution rate (Stage III) has been shown to be related to the formation of the $\mathrm{Al}^{3+}$-rich zeolite, analcime, and/or other calcium silicate phases [1] at (SA/V)•time values between $20,000 \mathrm{~m}^{-1}$ and $100,000 \mathrm{~m}^{-1}$ (see Section 2.4).

\subsection{Aging of HLW Glass Gel Layers: Enrichment in $\mathrm{Al}^{3+}$ versus $\mathrm{Fe}^{3+}$}

Experimental aging of the hydrated gel layers formed during Stage II glass dissolution has shown that the gel layer components age in situ into either clay mineral assemblages or zeolite mineral assemblages $[46,47,48,49,50]$. In order to understand the aging of a leached glass gel layer into either clay or zeolite mineral assemblages, it is important to recognize that the hydrated gel layer exhibits acid/base properties which are manifested as the $\mathrm{pH}$ dependence of the thickness and nature of the gel layer [51]. The alteration of aluminosilicate gels (artificial or natural) to clay or zeolites is $\mathrm{pH}$ dependent, with clay formation favoring less basic aging environments than zeolites [52]. Thus, if the solution $\mathrm{pH}$ changes while the gel ages a clay mineral species may convert into a zeolite mineral species in response to an increase in $\mathrm{pH}$.

The in-situ aging of an aluminosilicate rich leached layers in HLW glasses mimics the aging of aluminosilicate gels: artificially produced gels and those found in nature. Aluminosilicate gels that were co-precipitated under controlled laboratory conditions were aged into a variety of natural clays (smectities, beidellites, saponites, sauconites and montmorillonites) [53,54,55]. Aluminosilicate gels found in natural geothermal systems in an alkaline environment were harvested and then aged in the laboratory to the zeolite analcime [56]. The alteration of aluminosilicate gels (artificial or natural) to clay or zeolites is $\mathrm{pH}$ dependent, with clay formation favoring less basic aging environments than zeolites 
[57]. Aging of leached gel layers in natural environments, e.g. weathering of altered rhyolitic (acidic) volcanic glass, has been shown to alter in situ to both zeolites (clinoptilolite) and clays (smectitie, montmorillonite), and sometimes opal (hydrous silica) $[56,58,59]$.

Conversely, sequential aging of nuclear waste glass gel layers that were enriched in iron under controlled laboratory conditions produced montmorillonite clay [60] and the in situ formation of smectite clays has been determined to be dependent on the iron content of the dissolving glass [61]. The similarity of the gel layer formation and dissolution mechanism of iron containing borosilicate waste glasses and natural basalt glasses containing iron has been noted by several researchers, i.e. Morgenstein [62], Ewing [63], Malow [64], Allen [65], and Jantzen [66]. In particular, the work of Allen [65] indicated that the alteration layer on basalt glass is formed of cryptocrystalline iron rich clays grouped under the term “palagonite.” Likewise, the geochemical modeling (EQ3/EQ6) performed by Bourcier [67] on an iron rich waste glass gel layer composition predicted the formation of notronite $\left(\mathrm{Fe}_{2} \mathrm{Si}_{2} \mathrm{O}_{7} \bullet 2 \mathrm{H}_{2} \mathrm{O}\right)$ the iron analogue of the Al-rich clay mineral kaolinite $\left(\mathrm{Al}_{2} \mathrm{Si}_{2} \mathrm{O}_{7} \bullet 2 \mathrm{H}_{2} \mathrm{O}\right)$. Additional comparisons of the aging sequences of basaltic glasses and nuclear waste glasses tested using the Vapor Hydration Test (VHT) have demonstrated that clays can only turn into zeolites as the solution becomes more basic and more saturated with silica and alumina during static durability testing $[49,50]$.

Moreover, the role of $\mathrm{Al}^{3+}$ and $\mathrm{Fe}^{3+}$ in the HLW glass, in the leached layer, and in the leachant has been shown to be involved in whether a glass maintains Stage II dissolution or reverts to the forward rate of dissolution, e.g. Stage III dissolution. Van Iseghem and Grambow [1] demonstrated that an $\mathrm{Al}^{3+}$ rich zeolite (analcime) formed on certain glasses during dissolution but not on others. The formation of analcime in these experiments carried out at $90^{\circ} \mathrm{C}$ at SA/V conditions of 10,100 , and $7800 \mathrm{~m}^{-1}$ accelerated the glass corrosion by consuming $\mathrm{H}_{4} \mathrm{SiO}_{4}$ from the leachate solution but did not accelerate the glass corrosion back to the original forward rate, e.g. "the formation rate of analcime is too small to bring the glass dissolution rate back to the forward rate" [1]. The two different glasses were studied, SM58 which contained $1.2 \mathrm{wt} \% \mathrm{Al}_{2} \mathrm{O}_{3}$ and $1.2 \mathrm{wt} \% \mathrm{Fe}_{2} \mathrm{O}_{3}$ and SAN60 which contained $18.1 \mathrm{wt} \% \mathrm{Al}_{2} \mathrm{O}_{3}$ and $0.3 \mathrm{wt} \% \mathrm{Fe}_{2} \mathrm{O}_{3}$. The SAN60 glass with the highest concentrations of $\mathrm{Al}_{2} \mathrm{O}_{3}$ and the lowest amount of $\mathrm{Fe}_{2} \mathrm{O}_{3}$ was the glass that formed the analcime reaction product. These authors also demonstrated that a change in solution $\mathrm{pH}$ accompanied the return to the forward rate when analcime formed. Likewise, Inagaki [68] demonstrated that solution $\mathrm{pH}$ and solution concentrations of $\mathrm{Na}$ and $\mathrm{K}$ were also involved in the formation of analcime versus Na-bedellite (a smectite clay). Other zeolites and smectite clays that are rich in $\mathrm{Fe}^{3+}$ compared to $\mathrm{Al}^{3+}$ do not appear to accelerate glass corrosion $[1,69]$.

Thus, research has shown [70] that different $\mathrm{pH}$ values are achieved during static testing at different $\mathrm{SA} / \mathrm{V}$ ratios and that affects the reaction rate and the phases that form. This is important when studying or comparing the results of accelerated laboratory tests to burial tests: are the $\mathrm{SA} / \mathrm{V} \bullet$ conditions equivalent, is the alteration extent equivalent, and is the

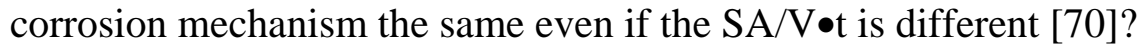


For the burial studies examined to date (Sections 1.2.1 and 1.2.2), the leached layers have generally been found to be enriched in $\mathrm{Fe}^{+3}$ rich phase such as the clay mineral nontronite or an Mg-Fe phase where the Mg component was supplied from the surrounding clay. For example, (1) the "ferromagnesian" rich leached layers observed in the CRNL field burial tests [13], (2) the $\mathrm{Fe}_{2} \mathrm{O}_{3}$ rich hematite mineral phases found on the Russian $\mathrm{K} 26$ burial glass [22], and (3) the notronites predicted by EQ3/EQ6 geochemical code from the Russian K26 burial glass leached layer compositions [18,71].

\section{Experimental}

As a part of a radionuclide migration research program, SRNL initiated a lysimeter project in 1978 to study the migration of low-level transuranic (TRU) contaminates from various waste forms buried under actual field conditions. A HLW glass cylinder $(1.3 \mathrm{~cm}$ in diameter and $1.3 \mathrm{~cm}$ in length), representing a Defense Waste Processing Facility (DWPF) HLW glass, was buried in 1981. The glass was exposed to natural rainfall in the unsaturated zone for 11 years. The glass lysimeter was then capped to minimize groundwater infiltration for 5 years. The lysimeter was then core sampled and the sample left in a $16^{\circ} \mathrm{C}$ cooler for another 9 years. Therefore, the glass was exposed to weather conditions for 15 years and in contact with moist soil for 24 years.

\subsection{Fabrication of the HLW Glass}

Defense HLW was once an acid waste that was neutralized for storage in carbon steel tanks. The neutralization caused the waste to settle into a thick sludge component and a low density salt supernates. The glass was made with Tank 15 waste which is a high alumina containing HLW waste sludge. The alumina is present as $\mathrm{Al}(\mathrm{OH})_{3}, \mathrm{AlOOH}$, $\mathrm{Al}(\mathrm{OH})_{4}{ }^{-}$, and other soluble aluminum salts. The high aluminum content is detrimental to making a quality vitrified product at reasonable waste loadings [72].

A large sample of Tank 15 waste had been retrieved from the tank in 1978. Several aluminum removal processes were tested in the SRNL Shielded Cell Facility to remove the soluble alumina in water and/or excess $\mathrm{NaOH}$ [72]. One test was performed in water only, two tests were performed in boiling 5 molar $\mathrm{NaOH}$, and the fourth test was performed with 3 molar $\mathrm{NaOH}$. The caustic treated sludges were mixed with water and centrifuged several times to "wash" the soluble salts out of the sludge in order to make a durable glass with a soluble salt level $<2 \mathrm{wt} \%$ on a dry basis. The alumina containing liquors can then be stabilized in cement.

At the end of the various Al dissolution and "washing” demonstrations the three caustic washed sludges were blended back together and reslurried with water [72]. The sludge slurry was fed to a fluid-bed calciner with a bed temperature of $350^{\circ} \mathrm{C}$. The washed and dried Tank 15 sludge was mixed with Frit $211\left(\mathrm{SiO}_{2}=58.3, \mathrm{~B}_{2} \mathrm{O}_{3}=11.1, \mathrm{Na}_{2} \mathrm{O}=20.6\right.$, $\mathrm{Li}_{2} \mathrm{O}=4.4$, and $\mathrm{CaO}=5.6$ ) in a weight ratio of 35/65 dried waste/sludge which is $\sim 28 \mathrm{wt} \%$ waste loading when all of the remaining insoluble nitrates, oxalates, and sulfates are destroyed at temperatures between the drying temperature of $350^{\circ} \mathrm{C}$ and the vitrification temperature of $1150^{\circ} \mathrm{C}$. 
The glass was processed through a Joule heated melter in the Shielded Cell Facility in SRNL at a temperature of $1150^{\circ} \mathrm{C}$. Most of the glass was collected in $500 \mathrm{~mL}$ stainless steel beakers. At the end of two of the melt campaigns, glass samples were poured into small graphite molds and archived for leaching experiments. The filled glass canisters and the graphite molds were allowed to slow cooled in a brick fort beside the melter to simulate the slow cooling of a DWPF type canister although a rigorous annealing schedule was not adhered to. The glass was not analyzed. One of the small graphite mold samples was the burial glass examined in this study.

The radionuclide concentrations in the glass were calculated from the radionuclides measured in the sludge as given in reference 72 accounting for the sludge density, sludge washing percent, the calcine oxide factor, the waste loading, and the weight of the glass pellet. In other words, the radionuclide loading in the glass pellet at the time of burial is given by the values in Table II. The primary radionuclide in the Tank 15 sludge was ${ }^{90} \mathrm{Sr}$.

\subsection{Burial and Retrieval of the HLW Glass}

The lysimeter consisted of an inverted 52-L bottomless carboy that was connected to a leachate collection reservoir. The lysimeter was filled with well-mixed subsurface sediment collected from a 4-m-deep pit from which the surface soil had been removed. The sediment used in this study was primarily collected from the vadose zone and contained no observable biological materials. The sediment had a $\mathrm{pH}$ of 6.3, total Fe concentration of $1.6 \mathrm{wt}-\%$, a sand, silt and clay content of 71,10 , and 19 wt-\%, respectively, and a clayfraction consisting of kaolinite, hematite, goethite, gibbsite and quartz.

The glass pellet (described in section 3.3) was placed $21.6 \mathrm{~cm}$ below the lysimeter sediment surface on the centerline of the carboy in lysimeter M2. The lysimeter was left exposed to natural weather conditions for 11 years before being capped for an additional 5 years. During operation, leachate from the lysimeter was periodically sampled (May 1981 to December 1989) and analyzed for gross alpha, gross beta/gamma, and ${ }^{137} \mathrm{Cs}$. Samples were taken monthy from 1981 until June 1983 when the sampling frequency was changed to quarterly. After 1987 the sampling frequency was irregular and sometimes $\sim 6$ months. The data from this time period are erratic and not used in this study. The alpha and gross beta/gamma measured with a Baird Instruments detector attached to a Scintillation Counter. A control lysimeter (M11) was also monitored and the alpha counts in the control lysimeter was often higher than the counts in the glass lysimeter. This is likely because the alpha emitters $\left({ }^{238} \mathrm{Pu}\right.$ and $\left.{ }^{239} \mathrm{Pu}\right)$ in the glass pellet are of very low concentration (Table II) compared to the beta emitter $\left({ }^{90} \mathrm{Sr}\right)$. Since the alpha data collected is below the detection limit of the instrument (as determined by counting of the percolate from the control lysimeter) this data is not used in the durability modeling presented in a subsequent section. Only two 137Cs measurements were made and this data was insufficient for durability modeling. Data that was below detection limit for $\beta / \delta$ was also not used in modeling.

At the end of the exposure period, the lysimeter was cored and the core was cut into fourteen 1.25 to $2.5 \mathrm{~cm}$ slices. These depth discrete sediment samples were acid digested 
and then analyzed for ${ }^{239 / 240} \mathrm{Pu}$ and ${ }^{137} \mathrm{Cs}$. As discussed above, the glass pellet was exposed to natural climatic conditions for $\sim 15$ years and was in contact with moist soil for 24 years.

\subsection{Characterization of the HLW Glass}

After the Tank 15 glass was unburied the following analyses were performed:

- Contained X-ray Diffraction (CXRD) of the glass surface

- Analysed performed on a Bruker D8 Advanced X-Ray Diffractometer with $\mathrm{CuK}_{\alpha}$ radiation at $45 \mathrm{KV}$ and $40 \mathrm{~mA}$

- Contained Scanning Electron Microscopy (CSEM) of the glass/soil layer interface

- Analyses performed on a LEO-440 Scanning Electron Microscope. The Energy Dispersive Spectra (EDS) were acquired using an Oxford Inca microanalysis system

- The sample was embedded in epoxy and sectioned perpendicular to the glass/soil interface

- Whole element chemistry of the bulk glass by

- $\quad$ Dissolution by $\mathrm{Na}_{2} \mathrm{O}_{2}$ with an $\mathrm{HCl}$ uptake followed by Inductively Coupled Plasma (ICP) - Emission Spectroscopy (ES) for Al, B, Ba, Ca, Ce, Cr, Cu, Fe, La, Li, Mg, Mn, Mo, Ni, Si, Sn, Sr, Ti, and U and ICP-Mass Spectroscopy (MS) for Th

- $\quad$ Dissolution by $\mathrm{HCl} / \mathrm{HF}$ bomb followed by ICP-ES for Na, Zn, and Zr

Anions were not measured as the anion content of the glass was predicted to be very low from analysis of the Tank 15 sludge [72] and analysis of the washed/dried sludge [73]. Glasses were analyzed in duplicate and both the Environmental Assessment (EA) glass [74] and the ARG-1 glass [75] were used as glass standards.

\subsection{Durability Testing of the HLW Glass}

There was not enough of the Tank 15 burial glass left to perform triplicate ASTM C1285 (Product Consistency or PCT) durability testing. A glass of the same composition was fabricated in crucibles and rapidly quenched. This glass was analyzed as shown in Section 3.3 and tested via ASTM C1285 (PCT-A). The results of the PCT test are expressed in this study as a normalized concentration $\left(\mathrm{NC}_{\mathrm{i}}\right)$ which has the units of $\mathrm{g}_{\text {waste }}$ form $/ \mathrm{L}_{\text {leachant }}$, where " $\mathrm{i}$ " is the chemical element of interest. Expression of the PCT test response as $\mathrm{NC}_{\mathrm{i}}$ does not necessitate the use of the surface area (SA) of the sample releasing species "i”" as the surface area is fixed by the strict control of the particle size during the PCT-A test ${ }^{\ddagger}$ and the control of the volume of the leachant being used which is expressed as the $\mathrm{SA} / \mathrm{V}$ ratio,

$\ddagger \quad$ The glasses were ground and sized between -100 and +200 mesh $(74 \mu \mathrm{m}$ to $149 \mu \mathrm{m})$. To remove the electrostatic fines, the sized material was washed six times with $100 \%$ ethanol. Water was not used for washing for fear of removing any water soluble phases prior to leaching as cautioned by the ASTM 


$$
\left.N C_{i}=\frac{c_{i}(\text { sample })}{f_{i}} \quad \text { (Equation } 1\right)
$$

where $\quad N C_{i}$ is the normalized release ( $\left.\mathrm{g}_{\text {waste form }} / \mathrm{L}_{\text {leachate }}\right)$

$c_{i}$ (sample) is the concentration of element $i$ in the leachate solution $\left(\mathrm{g}_{\mathrm{i}} / \mathrm{L}\right)$

$f_{i}$ is the fraction of element $i$ in the unleached waste form (unitless).

\section{Results and Discussion}

\subsection{Analysis of the Disposal Environment and Lysimeters}

A photograph of a recovered glass fragment is presented in Figure 2. The entire glass cylinder could be reconstructed from the fragments collected in the sediment. The cumulative mass of leachate ${ }^{239 / 240} \mathrm{Pu}$ and ${ }^{137} \mathrm{Cs}$ from the glass lysimeter was less than or equal to that for a control lysimeter containing no added radionuclides. This indicates neither of these radionuclides left the lysimeter with the leachate.

Additional radionuclide profiling for ${ }^{137} \mathrm{Cs}$ and ${ }^{90} \mathrm{Sr}$ indicated that these elements were enriched in the first few centimeters of soil surrounding the glass pellet (Figure 3). The ${ }^{137} \mathrm{Cs}$ and ${ }^{90} \mathrm{Sr}$ leached from the glass containing lysimeter were strongly sorbed by iron oxyhydroxides in the soil column as determined in the CRNL study.

The ${ }^{239 / 240} \mathrm{Pu}$ and ${ }^{137} \mathrm{Cs}$ mass balance in the lysimeters was conducted by summing the 14 individual soil cores to account for the total radionuclide concentration in the sediment and by summing the mass of radionuclides in the 41 leachate. The mass associated with the glass was determined by difference. The percentage of ${ }^{239 / 240} \mathrm{Pu}$ measured in the lysimeter sediment was $2.1 \times 10^{-4} \mathrm{wt}-\%\left(\mathrm{Ci}_{\text {sediment }} / \mathrm{Ci}_{\text {glass at } \mathrm{t}=24 \mathrm{yr}} \mathrm{x} 100\right)$ and in the leachate was $<9.2$ $10^{-4}$ wt-\%. This left 99.99887 wt-\% of the Pu remained in the glass (Table III). Slightly more ${ }^{137}$ Cs was released from the glass; $0.461 \mathrm{wt}-\%$ was measured in the sediment and $<1.36 \times 10^{-3}$ wt-\% measured in the leachate. Leaving $99.5 \mathrm{wt}-\%$ of the ${ }^{137} \mathrm{Cs}$ remaining in the glass (Table III). The finding of greater retention of Pu than Cs by glass has been previously reported.

\subsection{Analysis of the HLW Glass}

\subsubsection{Chemical Analysis and Comparison to Other Burial Glasses}

The analyses performed on the burial glass are described in Section 3.3. The burial glass and the standards were dissolved in duplicate and each analyte was analyzed once. The non-radioactive standards were analyzed simultaneously and handled in the same manner as the burial glass. The replicate analyses of the burial glass and the standards were

C1285-02 procedure. For all samples, ASTM Type I water1 was used as the leachant, a constant leachant to sample ratio of $10 \mathrm{~cm}^{3} / \mathrm{g}$ or $0.01 \mathrm{~L} / \mathrm{g}$ was used, the test temperature was $90^{\circ} \mathrm{C}$. The test duration was seven days. The test temperature and duration are the nominal test conditions used for testing glass waste form performance, e.g. PCT-A. Stainless steel vessels were used. 
averaged. The responses for several elements in the standards were biased either high (Ca, $\mathrm{Fe}, \mathrm{Mn}$ ) or low (Al, B, Na,). Glass compositions were bias corrected to the standard glasses for all elements that were in error by $\geq 4 \%$. The overall composition of the glass is given in Table I. The composition was normalized to $100 \%$ so that the frit and waste loadings could be calculated from the B and Li composition of the frit given in Section 3.1. The waste loading was calculated to be $\sim 31 \mathrm{wt} \%$. The radioactivity was calculated to be $\sim 0.25 \mathrm{MBq} / \mathrm{g}$.

The SRNL burial glass composition, waste loading, and radioactivity are compared to those of the CRNL burial glass, the Belgian doped glass burial studies, and the Russian K26 glass. The SRNL burial glass waste loading was high but the total radioactivity was low compared to the other radioactive burial studies given in Table II.

\subsubsection{Scanning Electron Microscopy and X-Ray Diffraction}

The X-ray Diffraction (XRD) of the SRNL burial glass surfaces was performed on four different samples. The primary phases were kaolinite clay from the surrounding soil and quartz $\left(\mathrm{SiO}_{2}\right)$. In two of the four samples gibbsite $\left(\mathrm{Al}(\mathrm{OH})_{3}\right)$ and/or boehmite $(\mathrm{AlOOH})$ were indicated as minor probable phases. Any other components were either below detection limit or amorphous.

Scanning Electron Microscopy with backscatter elemental mapping was performed of the glass/soil interface. A very thin leached layer that ranged in thickness from $<8 \mu \mathrm{m}$ to 8 $\mu \mathrm{m}$ with occasional regions as thick as $32 \mu \mathrm{m}$ were observed (Figure 4). The leached layer of the SRNL burial glass is much smaller than the 200-350 $\mu$ m leached layers observed in the Belgium doped burial studies at $90^{\circ} \mathrm{C}$. This is to be expected as the SRNL study was conducted at ambient temperatures.

The SRNL burial glass leached layers are somewhat thicker ( 10X) than the CRNL nepheline syenite glass leached layers. This is also expected as the high temperature, boron free, nepheline syenite glass is more durable than lower temperature borosilicate type glasses. In addition, the SRNL glass was buried for 5 years longer than the CRNL glass.

The SRNL burial glass leached layer is about the same order of magnitude as the Russian K26 glass leached layer indicating that 2-8 $\mu \mathrm{m}$ may be typical of borosilicate glasses buried at ambient conditions for $12-25$ years. Assuming that a maximum of $\sim 8 \mu \mathrm{m}$ $(0.008 \mathrm{~cm})$ leached uniformly around the SRNL burial pellet $(1.3 \mathrm{~cm}$ diameter and $1.3 \mathrm{~cm}$ high), and given that the surface area of the pellet is $\sim 5.31 \mathrm{~cm}^{2}$, an average of $0.06 \mathrm{~cm}^{3}$ of the total volume of $1.72 \mathrm{~cm}^{3}$ leached or $2.5 \%$.

The SEM/EDAX elemental mapping of the glass/soil interface (Figure 4) demonstrates that the leached layer is enriched in $\mathrm{Si}, \mathrm{Al}$, Fe and $\mathrm{K}$ while depleted in $\mathrm{Na}, \mathrm{Ca}, \mathrm{Mn}$. There are isolated nodules of a Ca rich phase in the soil that may be $\mathrm{CaCO}_{3}$ as observed in the K26 glass leached layers. The enrichment of Al, Fe, Si and $\mathrm{K}$ was also noted in the CRNL and Belgium burial studies. 


\subsection{Durability Testing of the HLW Glass}

A simulated Tank 15 glass was made for durability testing since the amount of burial glass was insufficient for triplicate durability analyses by ASTM C1285 (Product Consistency Test, PCT). The simulated glass was analyzed by the same methods as used on the burial glass (Section 3.3) and the analysis is given in Table I and shown to be very similar to the composition of the burial glass. The ASTM C1285 leachate data was calculated using Equation 1 and the results are given in Table IV. Two standards, the Approved Reference Material (ARM-1) and the Environmental Assessment (EA) glass were run as internal standards during the leaching experiment. The analysis of the standards from this study is given in Table IV and the results are compared to round robin results for each of these standard glasses. These results demonstrate that the Tank 15 glass durability measurements were in control.

\subsection{Comparison of Measured Durability to Predicted Glass Durability}

It is of interest to compare the predicted durability of the Tank 15 glass from the durability model THERMO ${ }^{\mathrm{TM}}[23,24]$ to the measured durability in the accelerated short term (7 day) ASTM C1285 (PCT) test. The ASTM C1285 test results are given in Table IV in terms of $\mathrm{NC}_{\mathrm{i}}$ (Equation 1) in g/L and shown graphically in Figure 5 plotted against the composition term, the preliminary free energy of hydration. The measured Tank 15 glass durability from the short term laboratory testing agrees well with the THERMO ${ }^{\mathrm{TM}}$ model prediction.

\subsection{Prediction of Stage I-Stage II Diffusion Controlled Behavior}

The rainfall, total alpha in $\mathrm{pCi} / \mathrm{mL}$, and total beta/gamma in $\mathrm{pCi} / \mathrm{mL}$ in the lysimeter was measured from May 1981 to November 1989 (Figure 7 top). The rainfall data was converted to an effluent volume assuming a standard $0.66 \%$ evapo-trasporation factor due to the warm climate in South Carolina all year long. Since the evapo-trasporation factor is a constant it does not affect the discussion of Stage I and Stage II diffusion controlled behavior of the Tank 15 glass. The time dependence of the groundwater volume and the specific radioactivity of the groundwater that contacted the waste glass (Figure 7 bottom) followed a square root dependency with time.

The groundwater concentration data $(\mathrm{pCi} / \mathrm{mL})$ measured with the Baird Scintillation Counter were converted to $\mathrm{Bq} / \mathrm{L}$ to be consistent with the dissolution modeling of Ojovan et. al. [20]. The volume of the individual effluents collected and measured at the jth time interval is $v_{\mathrm{j}}$ where

$$
V(t)=\sum_{t=j} v_{j}
$$


The total effluent collected, $\mathrm{V}(\mathrm{t})$, after 8.57 years (3129 days) was $253.9 \mathrm{~L}$. The amount of radionuclide $i$, expressed as $\beta / \delta$, leached out of the waste glass was calculated as $\mathrm{A}_{i}(\mathrm{t})$ in $\mathrm{Bq}$ from Equation 3

$$
A_{i}(t)=\sum_{t=j} a_{i j} v_{j} \quad \text { (Equation 3) }
$$

The normalized mass loss of radionuclide $i, \mathrm{NM}_{i}$ is then expressed in $\mathrm{g} / \mathrm{cm}^{2}$ from Equation 4

$$
N M_{i}=\frac{A_{i}(t)}{q_{i} S}
$$

Where $\mathrm{S}$ is the surface area of the glass monolith $\left(7.96 \mathrm{~cm}^{2}\right)$ and $\mathrm{q}_{\mathrm{i}=\beta / \delta}$ is $2.48 \times 10^{8} \mathrm{~Bq} / \mathrm{g}$. The glass monolith weighed $4.75 \mathrm{~g}$. The leached fraction of $\varphi_{\mathrm{I}}$, where i is $\beta / \delta$ is defined as

$$
\Phi_{i}=\frac{A_{i}(t)}{A_{i}(0)}
$$

where $\mathrm{A}_{\beta / \delta}(0)=1.18 \times 10^{9} \mathrm{~Bq}$ in the Tank 15 glass at burial.

Figure 8 shows the normalized mass loss and leached fraction of $\beta / \delta$ with time.

The average normalized leaching rate of radionuclide $\mathrm{i}, \mathrm{NR}_{\mathrm{i}}$, was calculated using

$$
N R_{i}=\frac{N M_{i}}{t}
$$

where $t$ is the duration of the test in days.

Figure 9 (top) shows the normalized leaching rate as a function of time. It can be seen from Figure 9 (top) that the overall leaching rate of $\beta / \delta$ progressively diminished with time resulting in a rate that is a half order of magnitude smaller than the initial rate after 7 years of burial. This is an intrinsic characteristic of a diffusion controlled process rather than a glass matrix dissolution via hydrolysis. The latter mechanism would show a constant leaching rate. Since Figure 9 (top) follows a square root dependency with time it indicates an ion exchange mechanism of glass corrosion rather than a linear hydrolysis mechanism [20]. The bottom of Figure 9 shows the time dependence of the normalized mass losses of $\beta / \delta$ divided by the square root of time $\left(N M_{i} / \sqrt{t}\right)$. Figure 9 (bottom) demonstrates that this ratio remains almost constant over the 7 year duration of the lysimeter measurements, which indicates that the $\beta / \delta$ are released from the Tank 15 glass via a diffusion controlled (Stage I-StageII) process. This is consistent with data from burial studies of low-level vitrified wastes [20,76]. 
In order to calculate an instantaneous leach rate, $\mathrm{NR}_{\mathrm{i}}$, in term of $\mathrm{g}_{\text {waste }}$ form $/ \mathrm{m}^{2} \bullet$ day the surface area of the glass exposed to the volume of leachant and the test duration must also be factored into the calculation as expressed in

$$
N R_{i}=\frac{c_{i}(\text { sample })}{\left(f_{i}\right) \bullet(S A / V) \bullet(t)} \quad \text { (Equation 6) }
$$

where $\quad N R_{i}$ is the normalized rate ( $\mathrm{g}_{\text {waste form }} / \mathrm{m}^{2} \bullet$ day)

$S A / V$ is the surface area of the waste form divided by the leachant volume $\left(\mathrm{m}^{2} / \mathrm{L}\right)$ $t$ is the time duration of the test (days)

\subsection{Prediction of Stage II Versus Stage III Behavior}

A new approach [27] based on Activated Complex Theory (ACT), was used to predict the return to the forward rate (Stage III) behavior for the burial glass compositions in Table I. The CRNL glass is excluded from this analysis as it is an aluminosilicate glass and not a borosilicate glass and the approach has only been investigated for borosilicate based waste glasses.

This approach is based on mineral moieties (clusters) in borosilicate waste glasses. The concentration of mineral moieties such as albite $\left(\mathrm{NaAlSi}_{3} \mathrm{O}_{8}\right)$, jadeite $\left(\mathrm{NaAl}_{2} \mathrm{Si}_{2} \mathrm{O}_{6}\right)$, nepheline $\left(\mathrm{NaAlSiO}_{4}\right)$, and acmite $\left(\mathrm{NaFeSi}_{2} \mathrm{O}_{6}\right)$ in a glass are determined from the glass composition. These compositions can be expressed on a ternary phase diagram composed of the end members $\mathrm{Si}, \mathrm{Al}$, and Fe in atomic \% when there is sufficient alkali in the glass to form any of the mineral moieties. Such a ternary is shown in Figure 6 and was developed using 217 glass compositions. The compositions of the Belgian/French, Russian, and US burial glasses are overlain on Figure 6.

Figure 6 demonstrates that glasses with high concentrations of albite (Ab) and acmite (Ac) are predicted to form ferrosilicate clay minerals on the leached glass surface and continue to leach at steady state (Stage II dissolution). Glasses with low Ab have more jadeite (Jd) insufficient Si to form acmite. In other words, the Al:Si ratio of the glass and the activated surface complexes are more favorable to the formation of analcime (zeolite) which has the same Al:Si ratio as Jd. The glasses with more Jd component are thus more likely to return to the forward rate of dissolution (Stage III). Most of the Belgium/French, and the Russian and US burial glasses all have sufficient Si (at\%) to maintain Stage II dissolution. Only the SAN60 and SM527 glasses are predicted to return to the forward rate (Stage III dissolution) and SAN 60 has been experimentally shown to do so [1].

The reaction of the mineral moieties in each glass can also be examined on a thermodynamic basis. If a glass is primarily an albite glass it cannot form analcime by reaction with water as the free energy of the reaction is not energetically favored, e.g. the free energy of formation of Equation 3 at $90^{\circ} \mathrm{C}$ is $+23.5 \mathrm{~kJ} / \mathrm{mol}$. 


$$
\underbrace{\mathrm{NaAlSi}_{3} \mathrm{O}_{8}}_{\text {albite }}+\mathrm{H}_{2} \mathrm{O} \stackrel{90^{\circ} \mathrm{C}}{\longrightarrow} \underbrace{\mathrm{NaAlSi}_{2} \mathrm{O}_{6} \bullet \mathrm{H}_{2} \mathrm{O}}_{\text {analcime }}+\mathrm{SiO}_{2}(\mathrm{aq})
$$

Equation 7

If a glass is primarily jadeite it is energetically favored $\left(\Delta \mathrm{G}_{\mathrm{fm}}=-9.8 \mathrm{~kJ} / \mathrm{mole}\right.$ at $\left.90^{\circ} \mathrm{C}\right)$ to form when reacted with water (Equation 8). Note also that the Al:Si ratio of Jd and analcime are the same so it is also structurally favored.

$$
\underbrace{\mathrm{NaAl}_{2} \mathrm{Si}_{2} \mathrm{O}_{6}}_{\text {jadeite }}+\mathrm{H}_{2} \mathrm{O} \stackrel{90^{\circ} \mathrm{C}}{\longrightarrow} \underbrace{\mathrm{NaAlSi}_{2} \mathrm{O}_{6} \bullet \mathrm{H}_{2} \mathrm{O}}_{\text {analcime }}
$$

If a glass is primarily nepheline, a source of aqueous $\mathrm{SiO}_{2}$ is needed for the formation of analcime in addition to $\mathrm{H}_{2} \mathrm{O}$ (Equation 9$)$ and the reaction is energetically favored $\left(\Delta \mathrm{G}_{\mathrm{fm}}=\right.$ $-38.2 \mathrm{~kJ} /$ mole at $90^{\circ} \mathrm{C}$ )

$$
\underbrace{\mathrm{NaAlSiO}_{4}}_{\text {nepheline }}+\mathrm{H}_{2} \mathrm{O}+\mathrm{SiO}_{2}(a q) \stackrel{90^{\circ} \mathrm{C}}{\longrightarrow} \underbrace{\mathrm{NaAlSi}_{2} \mathrm{O}_{6} \bullet \mathrm{H}_{2} \mathrm{O}}_{\text {analcime }} \quad \text { Equation } 9
$$

In the presence of excess $\mathrm{OH}^{-}$, nepheline glass moieties can form paragonite (Equation 10). The formation of paragonite from nepheline is energetically favored $\left(\Delta \mathrm{G}_{\mathrm{fm}}=-139 \mathrm{~kJ} / \mathrm{mole}\right.$ at $90^{\circ} \mathrm{C}$ ). In turn, paragonite can form analcime by reaction with more base and a source of aqueous $\mathrm{SiO}_{2}$ (Equation 11) and this is also energetically favored $\left(\Delta \mathrm{G}_{\mathrm{fm}}=-170 \mathrm{~kJ} / \mathrm{mole}\right.$ at $\left.90^{\circ} \mathrm{C}\right)$.

$$
\begin{aligned}
& \underbrace{3 \mathrm{NaAlSiO}_{4}}_{\text {nepheline }}+2 \mathrm{OH}^{-} \stackrel{90^{\circ} \mathrm{C}}{\longrightarrow} \underbrace{\mathrm{NaAl}_{3} \mathrm{Si}_{3} \mathrm{O}_{10}(\mathrm{OH})_{2}}_{\text {paragonite }}+2 \mathrm{Na}^{+} \\
& \underbrace{\mathrm{NaAl}_{3} \mathrm{Si}_{3} \mathrm{O}_{10}(\mathrm{OH})_{2}}_{\text {paragonite }}+2 \mathrm{NaOH}(a q)+3 \mathrm{SiO}_{2}(a q) \stackrel{90^{\circ} \mathrm{C}}{\longrightarrow} \\
& \underbrace{3 \mathrm{NaAlSi}_{2} \mathrm{O}_{6} \bullet \mathrm{H}_{2} \mathrm{O}}_{\text {analcime }}+\mathrm{H}_{2} \mathrm{O}
\end{aligned}
$$

However, if a glass has sufficient acmite in it and enough of an albite component then it is highly energetically favored $\left(\Delta \mathrm{G}_{\mathrm{fm}}=-604 \mathrm{~kJ} / \mathrm{mole}\right.$ at $\left.90^{\circ} \mathrm{C}\right)$ to form nontronite (a Fe rich clay mineral) and continue to leach at steady state rate (Equation 12). No excess aqueous $\mathrm{SiO}_{2}$ is needed for this reaction to occur.

$$
\begin{aligned}
& \underbrace{2 \mathrm{NaFeSi}_{2} \mathrm{O}_{6}}_{\text {acmite }}+\underbrace{0.33 \mathrm{NaAlSi} \mathrm{O}_{8}}_{\text {albite }}+2 \mathrm{H}_{2} \mathrm{O} \stackrel{90^{\circ} \mathrm{C}}{\longrightarrow} \underbrace{\mathrm{Na}_{0.33} \mathrm{Fe}_{2} \mathrm{Al}_{0.33} \mathrm{Si}_{3.67} \mathrm{O}_{10}(\mathrm{OH})_{2}}_{\text {nontronite }} \text { Equation } 12 \\
& +1.32 \mathrm{SiO}_{2}(a q)+2 \mathrm{NaOH}
\end{aligned}
$$


Thus glasses with insufficient Si to form albite moieties form jadeite or nepheline moieties and are more susceptible to forming analcime and returning to the forward rate of dissolution via Equations 8-11 than glasses with sufficient Si to form albite and sufficient Fe to form acmite (Equations 7 and 12). Equation 12 is the most likely reaction stabilizing an iron containing glass, Tank 15 SRS glass, at steady state (Stage II) dissolution.

\section{Conclusions}

The Tank 15 HLW burial glass was found to be very durable in both the burial environment and during accelerated laboratory durability testing. Surface layer formation was minimal and the surface layer was enriched in $\mathrm{Al}$ and $\mathrm{Fe}$. The surface layer was either a Type I or Type II which is similar to the surfaces identified for DWPF glasses using the MCC-1 test. The surface layer enrichment in Fe and the glass composition predict that this glass will not undergo Stage III dissolution, the return to the forward rate, but continue to leach at steady state Stage II rate.

The Tank 15 HLW burial glass was predicted to be durable using two different SRNL durability models (THERMO ${ }^{\mathrm{TM}}$ and ACT ${ }^{\mathrm{TM}}$ ) based on short term and long term durability testing with ASTM C1285 (Product Consistency Test). Short term durability measurement of the glass confirmed this.

Tank 15 HLW glass leached minimal radionuclides into the lysimeters and/or soil during 24 years of contact with moist soil. No detectable $\mathrm{Pu}, \mathrm{Am}, \mathrm{Cm}, \mathrm{Np}$, or $\mathrm{Ru}$ leached from the glass into the surrounding sediment. Less than $0.5 \%$ of the ${ }^{137} \mathrm{Cs}$ and ${ }^{90} \mathrm{Sr}$ in the glass leached into the surrounding sediment. Greater than $99 \%$ of the leached radionuclides remained within $8 \mathrm{~cm}$ of the glass pellet. The ${ }^{137} \mathrm{Cs}$ and ${ }^{90} \mathrm{Sr}$ leached from the glass were strongly bound by iron oxyhydroxides in the soil column as found in the Belgian and Canadian burial studies. Superior or equivalent performance of burial glasses in unsaturated and saturated sediments compared to saturated accelerated laboratory tests is consistent with other long term radioactive burial experiments in Canada, Belgium, and Russia.

\section{Acknowledgements}

The authors would like to thank Dr. S.B Clark of the Washington State University for her contribution to the early portion of this study. The authors would also like to acknowledge the assistance and support of Dr. G.G. Wicks of SRNL without whose assistance this publication may not have been completed. This research was sponsored by the Department of Energy (EM-50) by an Independent Research \& Development (IR\&D-2004) grant in connection with work done under Contract No. DE-AC09-96SR18500 with the U.S. Department of Energy. Since the burial studies were initiated in 1981 and the documentation completed in 2008 the work was performed under Contracts No. DE-AC0976SR00001, DE-AC09-89SR18035, and DE-AC-09-96SR18500 with the U.S. Department of Energy. 
Table I. Composition of the Tank 15 Burial Glass Made with High $\mathrm{Al}_{2} \mathrm{O}_{3}$ Containing $\mathrm{HLW}$ Waste

\begin{tabular}{|c|c|c|c|c|c|c|c|c|c|}
\hline $\begin{array}{c}\text { Oxide Species } \\
\text { (wt\%) }\end{array}$ & $\begin{array}{l}\text { SRNL } \\
\text { HLW } \\
\text { Burial } \\
\text { Glass }\end{array}$ & $\begin{array}{c}\text { SRNL } \\
\text { Simulated } \\
\text { Burial Glass }\end{array}$ & $\begin{array}{c}\text { SON 68 } \\
\text { (R7T7) } \\
{[8]}\end{array}$ & SM513 [8] & $\begin{array}{c}\text { SM527 } \\
\text { (Phase Sep } \\
\text { per NAS) [8] }\end{array}$ & WG124 [8] & $\begin{array}{c}\text { Canadian } \\
\text { HLW } \\
\text { Burial Test } \\
\# 1 \text { [14] }\end{array}$ & $\begin{array}{c}\text { Canadian } \\
\text { HLW } \\
\text { Burial Test } \\
\text { \#2 [14] }\end{array}$ & $\begin{array}{c}\text { Russian } \\
\text { LAW } \\
\text { K26 } \\
{[21,22,77]} \\
\end{array}$ \\
\hline $\begin{array}{l}\text { WASTE LOADING } \\
\text { (wt } \% \text { calcine oxide) }\end{array}$ & $\sim 31^{* *}$ & $\sim 31^{* *}$ & UNK & UNK & UNK & UNK & 1.5 & 8 & 35 \\
\hline RADIOACTIVITY $^{t}$ & $0.25 \mathrm{MBq} / \mathrm{g}$ & N/A & $\sim 1 \mathrm{GBq} / \mathrm{g}$ & $\sim 1 \mathrm{GBq} / \mathrm{g}$ & $\sim 1 \mathrm{GBq} / \mathrm{g}$ & $\sim 1 \mathrm{GBq} / \mathrm{g}$ & $\sim 90 \mathrm{MBq} / \mathrm{g}$ & $\sim 260 \mathrm{MBq} / \mathrm{g}$ & $3.75 \mathrm{MBq} / \mathrm{g}$ \\
\hline $\mathrm{Al}_{2} \mathrm{O}_{3}$ & 6.67 & 6.99 & 4.91 & $3.59^{\ddagger}$ & 19.96 & $2.9^{\ddagger}$ & 20.44 & 19.37 & $3.1^{\ddagger}$ \\
\hline $\mathrm{Am}_{2} \mathrm{O}_{3}$ & & & 0.85 & 0.85 & 0.85 & 0.85 & & & \\
\hline $\mathrm{BaO}$ & & & 0.60 & 0.10 & & 4.4 & & & \\
\hline $\mathrm{B}_{2} \mathrm{O}_{3}$ & 7.54 & 7.57 & 14.02 & 13.08 & 21.70 & & & & 6.6 \\
\hline $\mathrm{CaO}$ & 4.16 & 5.18 & 4.04 & 4.54 & 3.87 & 4.1 & 15.00 & 13.80 & 13.7 \\
\hline $\mathrm{Ce}_{2} \mathrm{O}_{3}$ & 0.22 & & 0.93 & 0.18 & & & & & \\
\hline $\mathrm{Cr}_{2} \mathrm{O}_{3}$ & 0.50 & 0.47 & 0.51 & 0.27 & 0.02 & 2.2 & & 0.18 & \\
\hline $\mathrm{Cs}_{2} \mathrm{O}$ & & & 1.29 & 0.126 & & & 0.0002 & 0.001 & \\
\hline $\mathrm{CuO}$ & 0.14 & & & & & 1.1 & & & \\
\hline $\mathrm{Eu}_{2} \mathrm{O}_{3}$ & & & & 0.01 & & & & & \\
\hline $\mathrm{Fe}_{2} \mathrm{O}_{3}$ & 10.08 & 9.94 & 2.91 & 1.67 & 0.7 & 12.5 & 0.06 & 2.30 & 1.7 \\
\hline $\mathrm{Gd}_{2} \mathrm{O}_{3}$ & & & & 0.008 & & & & & \\
\hline $\mathrm{K}_{2} \mathrm{O}$ & & & & & & 1.3 & 4.26 & 3.92 & 0.5 \\
\hline $\mathrm{La}_{2} \mathrm{O}_{3}$ & 0.04 & & 0.09 & 0.083 & & & & & \\
\hline $\mathrm{Li}_{2} \mathrm{O}$ & 3.02 & 3.11 & 1.98 & 4.18 & 3.10 & & & & \\
\hline $\mathrm{MgO}$ & 0.23 & 0.23 & & 2.05 & 0.14 & 2.9 & 0.02 & 0.22 & \\
\hline $\mathrm{MnO}$ & 1.79 & 1.74 & & 0.53 & 0.02 & & & & 0.95 \\
\hline $\mathrm{MoO}_{3}$ & & & & 0.28 & 0.05 & 2.1 & & & 0.95 \\
\hline $\mathrm{Na}_{2} \mathrm{O}$ & 13.74 & 14.83 & 9.86 & 9.05 & 7.77 & 3.6 & 8.53 & 11.39 & 23.9 \\
\hline $\mathrm{Nd}_{2} \mathrm{O}_{3}$ & & & 1.59 & 0.26 & 0.07 & & & & \\
\hline $\mathrm{NiO}$ & 0.82 & 0.69 & 0.41 & 0.42 & & 1.1 & & 0.20 & \\
\hline $\mathrm{NpO}_{2}$ & & & 0.85 & 0.85 & 0.85 & 0.85 & & & \\
\hline $\mathrm{PbO}$ & & & & & & & & & 0.95 \\
\hline $\mathrm{P}_{2} \mathrm{O}_{5}$ & & & 0.28 & 0.006 & & & & & 0.95 \\
\hline $\mathrm{Pr}_{2} \mathrm{O}_{3}$ & & & 0.44 & 0.077 & & & & & \\
\hline $\mathrm{PuO}_{2}$ & & & 0.85 & 0.85 & 0.85 & 0.85 & & 0.13 & \\
\hline $\mathrm{Sb}_{2} \mathrm{O}_{3}$ & 0.09 & & 0.0045 & 0.001 & & & & & \\
\hline
\end{tabular}




\begin{tabular}{|c|c|c|c|c|c|c|c|c|c|}
\hline $\begin{array}{c}\text { Oxide Species } \\
\text { (wt\%) }\end{array}$ & $\begin{array}{c}\text { SRNL } \\
\text { HLW } \\
\text { Burial } \\
\text { Glass } \\
\end{array}$ & $\begin{array}{c}\text { SRNL } \\
\text { Simulated } \\
\text { Burial Glass }\end{array}$ & $\begin{array}{c}\text { SON 68 } \\
\text { (R7T7) } \\
{[8]}\end{array}$ & SM513 [8] & $\begin{array}{c}\text { SM527 } \\
\text { (Phase Sep } \\
\text { per NAS) [8] }\end{array}$ & WG124 [8] & $\begin{array}{c}\text { Canadian } \\
\text { HLW } \\
\text { Burial Test } \\
\# 1 \text { [14] } \\
\end{array}$ & $\begin{array}{c}\text { Canadian } \\
\text { HLW } \\
\text { Burial Test } \\
\text { \#2 [14] } \\
\end{array}$ & $\begin{array}{c}\text { Russian } \\
\text { LAW } \\
\text { K26 } \\
{[21,22,77]}\end{array}$ \\
\hline $\mathrm{SiO}_{2}$ & 45.78 & 44.93 & 45.48 & 52.15 & 38.75 & 60.7 & 51.2 & 47.10 & 43.00 \\
\hline $\mathrm{Sm}_{2} \mathrm{O}_{3}$ & & & & 0.059 & & & & & \\
\hline $\mathrm{SnO}_{2}$ & 0.26 & & 0.18 & 0.004 & & & & & 0.95 \\
\hline $\mathrm{SrO}$ & 0.74 & & 0.33 & 0.045 & & & 0.023 & 0.006 & \\
\hline $\mathrm{ThO}_{2}$ & 0.11 & $<0.57$ & 0.33 & & & & & & \\
\hline $\mathrm{TiO}_{2}$ & 0.84 & 0.84 & 0 & 4.54 & 1.55 & 1.1 & & 0.01 & 0.95 \\
\hline $\mathrm{UO}_{2}$ & 2.43 & 2.67 & 0.52 & 0.104 & 0.02 & & & 0.96 & \\
\hline $\mathrm{Y}_{2} \mathrm{O}_{3}$ & & & 0.21 & 0.044 & & & & & \\
\hline $\mathrm{ZnO}$ & 0.02 & $<0.01$ & 2.50 & 0.016 & & & & & \\
\hline $\mathrm{ZrO}_{2}$ & 0.04 & 0.04 & 2.65 & 0.79 & 0.05 & & & & \\
\hline $\mathrm{Cl}$ & NM & NM & NM & NM & NM & NM & NM & NM & 0.67 \\
\hline $\mathrm{SO}_{4}$ & $\mathrm{NM}$ & $\mathrm{NM}$ & NM & 0.54 & 1.35 & NM & NM & NM & 0.74 \\
\hline Other ${ }^{\ddagger \ddagger}$ & NM & NM & 0.54 & 0.34 & & & & & \\
\hline SUM & 99.26 & 99.79 & 99.15 & 101.69 & 102.54 & 102.55 & 99.53 & 99.59 & 99.61 \\
\hline
\end{tabular}

* During development of THERMO ${ }^{\mathrm{TM}}$ it was determined that a minimum of $4 \mathrm{wt} \% \mathrm{Al}_{2} \mathrm{O}_{3}$ was necessary in high $\mathrm{Fe}_{2} \mathrm{O}_{3}$ containing and high $\mathrm{Na}_{2} \mathrm{O}$ containing glasses to avoid phase separation [78] unless sufficient $\mathrm{ZrO}_{2}$ was present as well. This is consistent with the known miscibility gap in the $\mathrm{Al}_{2} \mathrm{O}_{3}-\mathrm{Fe}_{2} \mathrm{O}_{3}-$ $\mathrm{Na}_{2} \mathrm{O}-\mathrm{SiO}_{2}$ quaternary system (no $\mathrm{ZrO}_{2}$ ) that defines the crystallization of basalt [79]. The $\mathrm{HLW}$ waste glasses with $<4.0$ wt $\% \mathrm{Al}_{2} \mathrm{O}_{3}$ were subject to poor durability due to the phase separation. Confirmation is also provided by commercial glasses in the $\mathrm{Na}_{2} \mathrm{O}-\mathrm{SiO}_{2}-\mathrm{Al}_{2} \mathrm{O}_{3}$ system which are known to phase separate when $\mathrm{Al}_{2} \mathrm{O}_{3}$ is $\leq 3 \mathrm{wt} \%$. [80, 81]

** Calculated from the $\mathrm{B}_{2} \mathrm{O}_{3}$ and $\mathrm{Li}_{2} \mathrm{O}$ compositions measured in the burial glass in this study once normalized to 100 wt\% and the Frit 211 composition given in Section 3.1 normalized to $100 \mathrm{wt} \%$.

㧊 $\mathrm{Rb}_{2} \mathrm{O}, \mathrm{CoO}, \mathrm{Ag}_{2} \mathrm{O}, \mathrm{CdO}, \mathrm{TeO}_{2}, \mathrm{RuO}_{2}, \mathrm{RhO}_{2}, \mathrm{PdO}$

$\mathrm{t}$ where $\mathrm{MBq}$ (megabecquerel, $10^{6} \mathrm{~Bq}$ ) and $\mathrm{GBq}$ (gigabecquerel, $10^{9} \mathrm{~Bq}$ ) 
Table II. Radionculide Content of the Initial Glass Monolith

\begin{tabular}{|c|c|}
\hline Radionuclide & $\mathrm{mCi} / 4.75 \mathrm{~g}$ \\
\hline${ }^{90} \mathrm{Sr}$ & 31.68 \\
\hline${ }^{144} \mathrm{Ce}$ & 0.12 \\
\hline${ }^{137} \mathrm{Cs}$ & 0.11 \\
\hline${ }^{60} \mathrm{Co}$ & 0.11 \\
\hline${ }^{154} \mathrm{Eu}$ & 0.08 \\
\hline${ }^{106} \mathrm{Ru}$ & 0.02 \\
\hline${ }^{125} \mathrm{Sb}$ & 0.02 \\
\hline${ }^{238} \mathrm{Pu}$ & 0.03 \\
\hline${ }^{239} \mathrm{Pu}$ & $<0.01$ \\
\hline
\end{tabular}

Table III. Mass balance for ${ }^{239} \mathrm{Pu}$ and ${ }^{137} \mathrm{Cs}$ between the glass, the soil sediment, and the lysimeter leachate.

\begin{tabular}{|c|c|c|}
\hline Media & ${ }^{239} \mathrm{Pu}$ & ${ }^{137} \mathrm{Cs}$ \\
\hline Glass & 1.000 & 0.995 \\
\hline Sediment & $2.1 \mathrm{E}-6$ & $4.61 \mathrm{E}-3$ \\
\hline Leachate & $<9.2 \mathrm{E}-6$ & $<1.36 \mathrm{E}-5$ \\
\hline
\end{tabular}


Table IV. Product Consistency Test (ASTM C1285) Results for the Tank 15 Simulated Glass and Standards Used During Testing

\begin{tabular}{|c|c|c|c|c|c|}
\hline & $\begin{array}{c}\text { ARM } \\
\text { Standard } \\
\text { (This } \\
\text { Study) }\end{array}$ & $\begin{array}{c}\text { ARM } \\
\text { (Published } \\
\text { Round } \\
\text { Robin) }\end{array}$ & $\begin{array}{c}\text { 75 } \\
\text { Standard } \\
\text { (This } \\
\text { Study) }\end{array}$ & $\begin{array}{c}\text { EA } \\
\text { (Published } \\
\text { Round } \\
\text { Robin) }\end{array}$ & $\begin{array}{c}\text { Tank 15 } \\
\text { HLW } \\
\text { Glass } \\
\text { (This } \\
\text { Study) }\end{array}$ \\
\hline Log $\mathrm{NC}_{(\mathrm{B})} \mathrm{g} / \mathrm{L}$ & -0.28 & -0.29 & 1.29 & 1.22 & -0.06 \\
\hline $\log \mathrm{NC}_{(\mathrm{Li})} \mathrm{g} / \mathrm{L}$ & -0.23 & -0.24 & 1.00 & 0.98 & -0.08 \\
\hline $\log \mathrm{NC}_{(\mathrm{Na})} \mathrm{g} / \mathrm{L}$ & -0.30 & -0.30 & 1.16 & 1.13 & -0.06 \\
\hline $\left.\log _{\mathrm{NC}} \mathrm{Si}\right) \mathrm{g} / \mathrm{L}$ & -0.55 & -0.55 & 0.62 & 0.59 & -0.36 \\
\hline
\end{tabular}




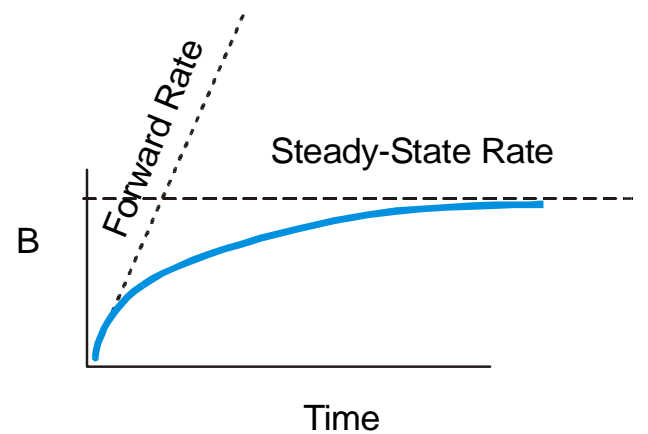

(a)

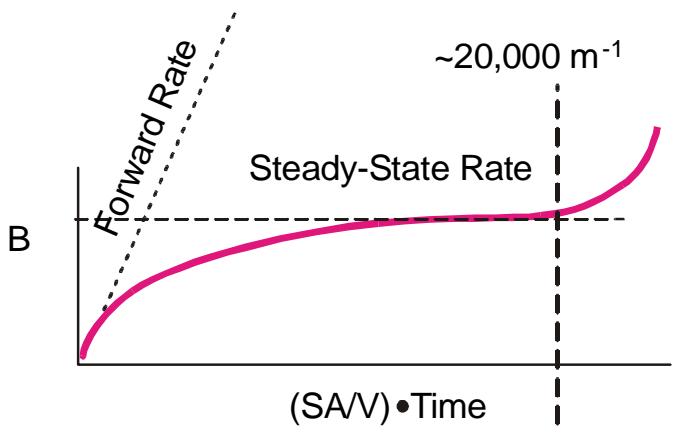

(b)

Figure 1. (a) Parabolic behavior of the diffusion of a soluble species out of the glass through an increasingly thick surface layer (b) Acceleration of glass durability tests using glass surface area (SA), leachant volume (V), and time. Acceleration appears to follow parabolic diffusion kinetics until $\sim 20,000 \mathrm{~m}^{-1}$ when the glass dissolution mechanism appears to change reverting to the forward rate.

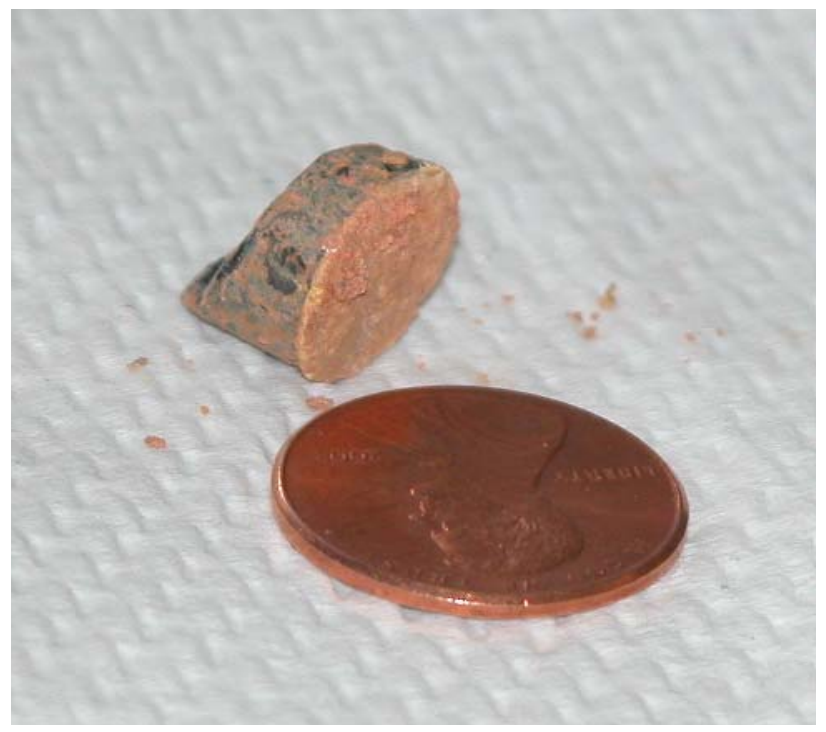

Figure 2. Burial glass fragment exhumed after 24 years. 


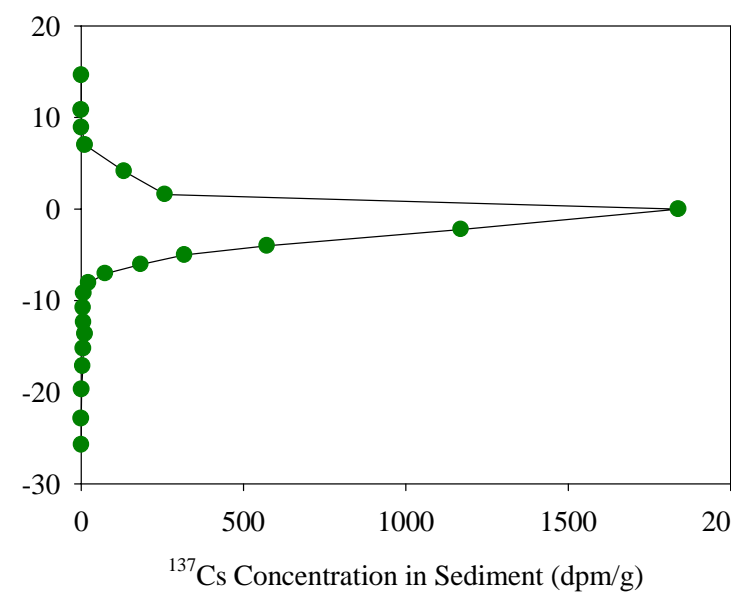

(a)

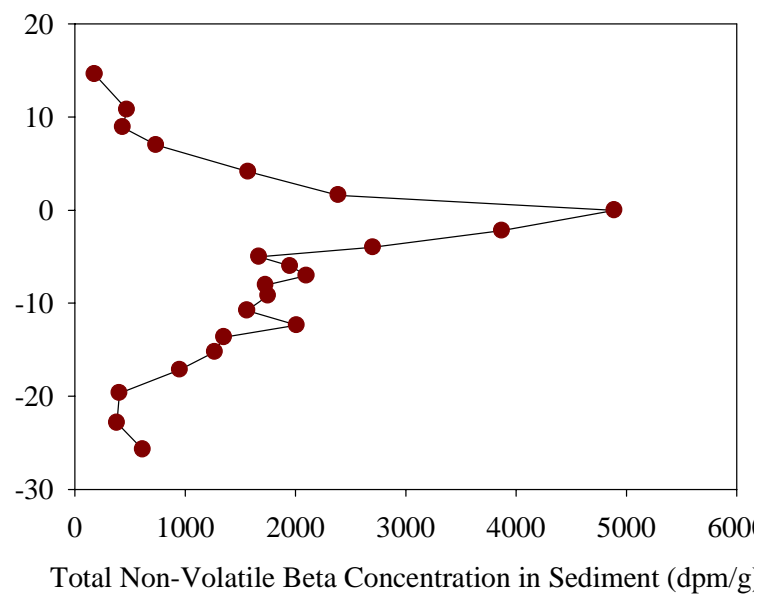

(c)

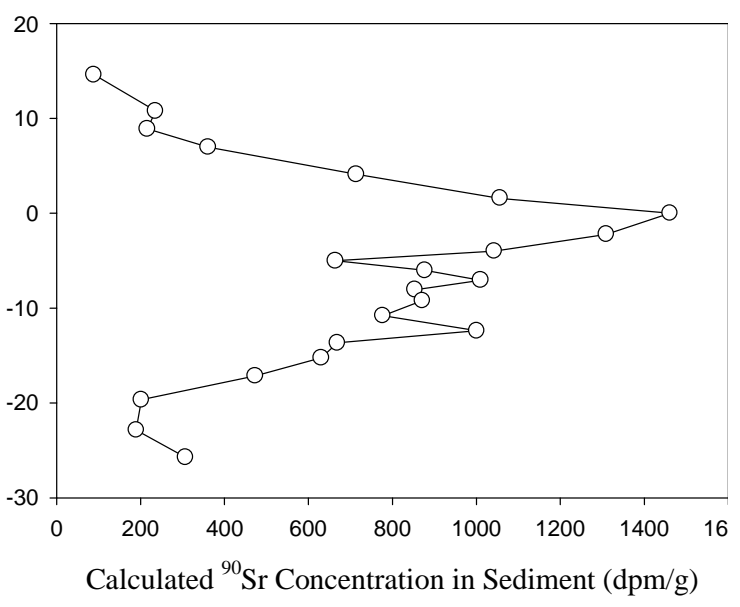

(b)

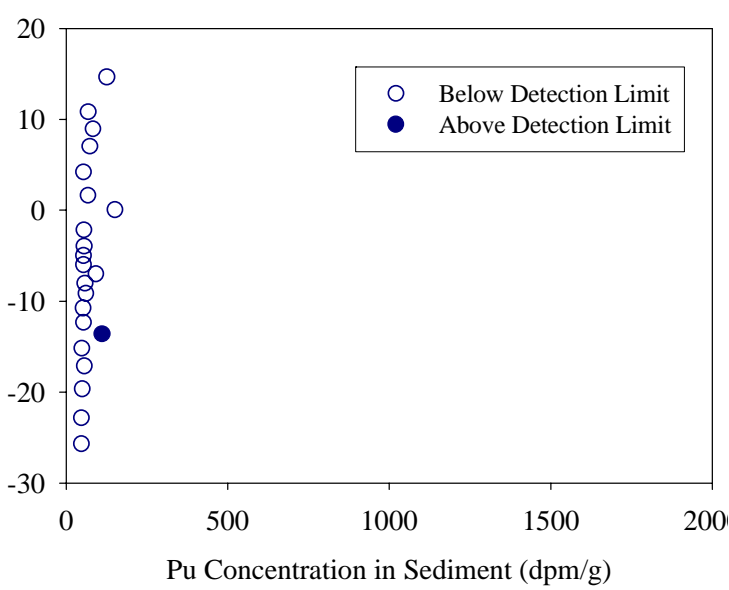

(d)

Figure 3. Radionuclide and activity distribution in sediment around buried glass pellet (initial activity in the glass was $5.3 \mathrm{e} 7 \mathrm{dpm}{ }^{238} \mathrm{Pu}, 2.6 \mathrm{e} 10 \mathrm{dpm}{ }^{90} \mathrm{Sr}$, and $1.3 \mathrm{e} 8$ dpm $\left.{ }^{137} \mathrm{Cs}\right)$. 


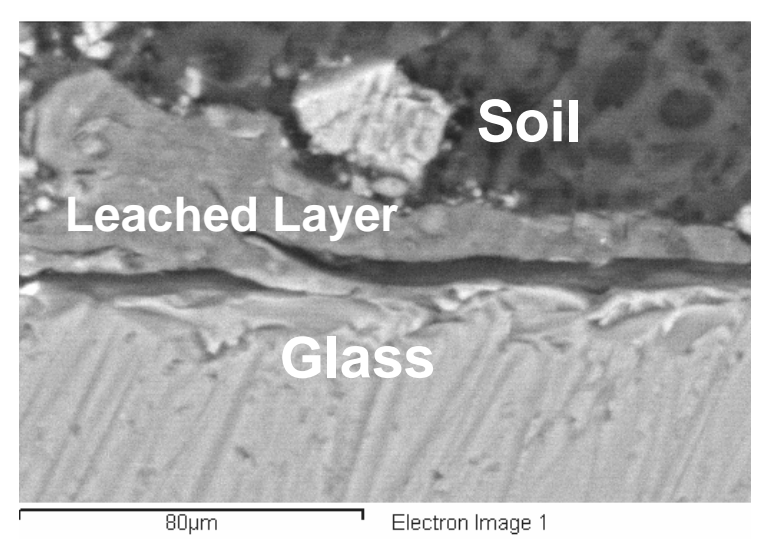

(a)

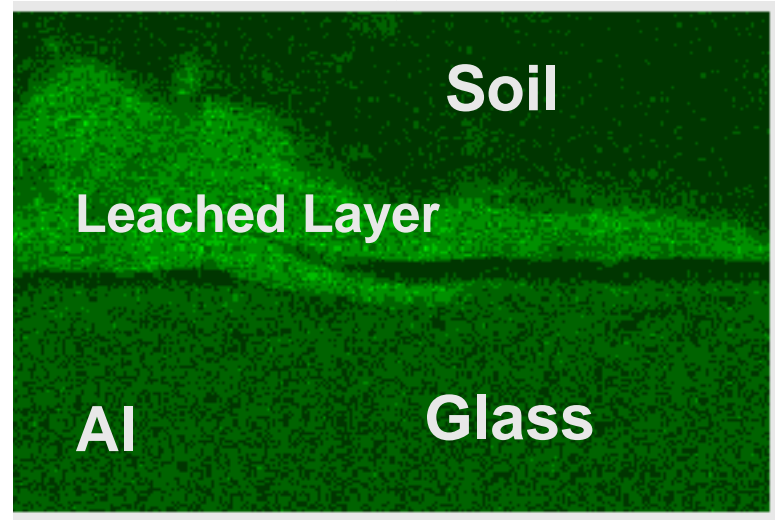

(c)

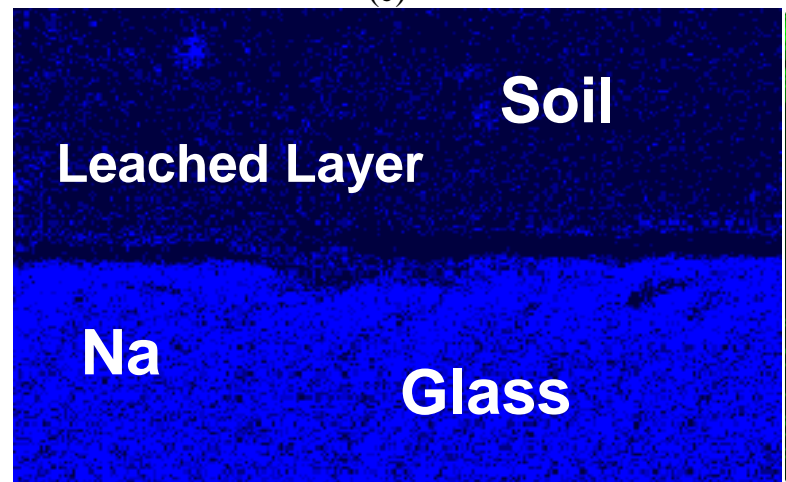

(e)

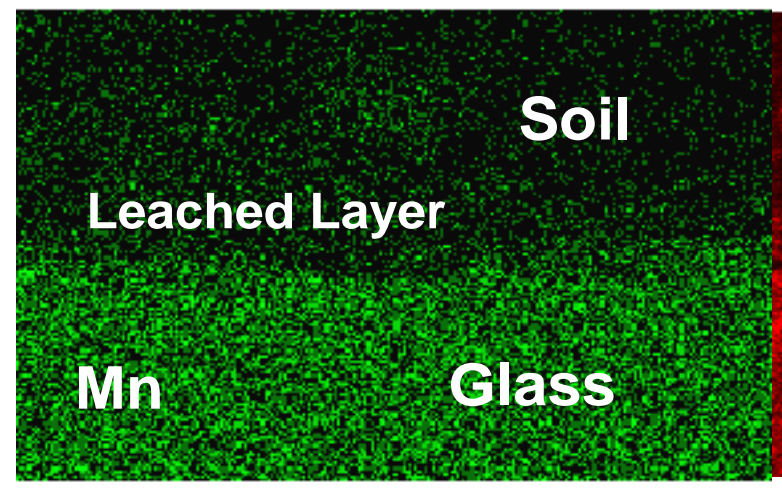

(g)

\section{Soil}

Leached Layer

Si

\section{Glass}

(b)

\section{Soil}

\section{Leached Layer}

$\mathrm{Fe}$

\section{Glass}

(d)

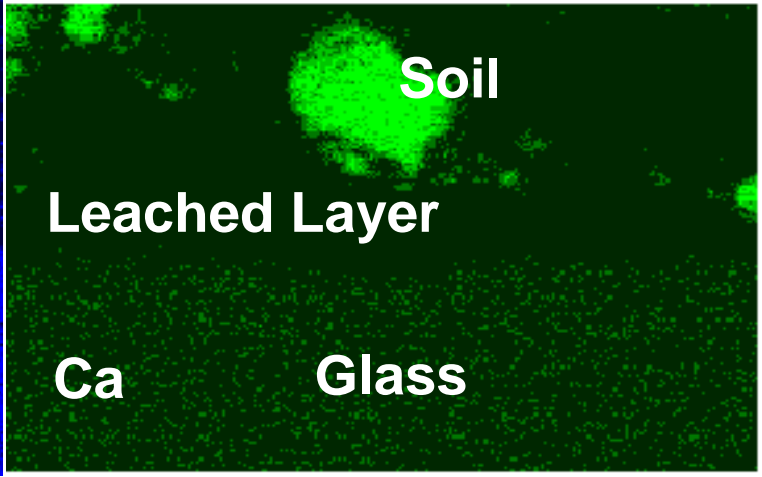

(f)

\section{Soil}

\section{Leached Layer}

$\mathrm{O}_{2}$

Glass 
Figure 4. Energy Dispersive Spectra for soluble species such as K, Na, Ca and insoluble species that participate in the leached layer formation ( $\mathrm{Si}, \mathrm{Al}$, and $\mathrm{Fe}$ ) and insoluble species that remain in the glass $(\mathrm{Mn})$. Note the nodule of a Ca rich species in the soil, likely $\mathrm{CaCO}_{3}$.

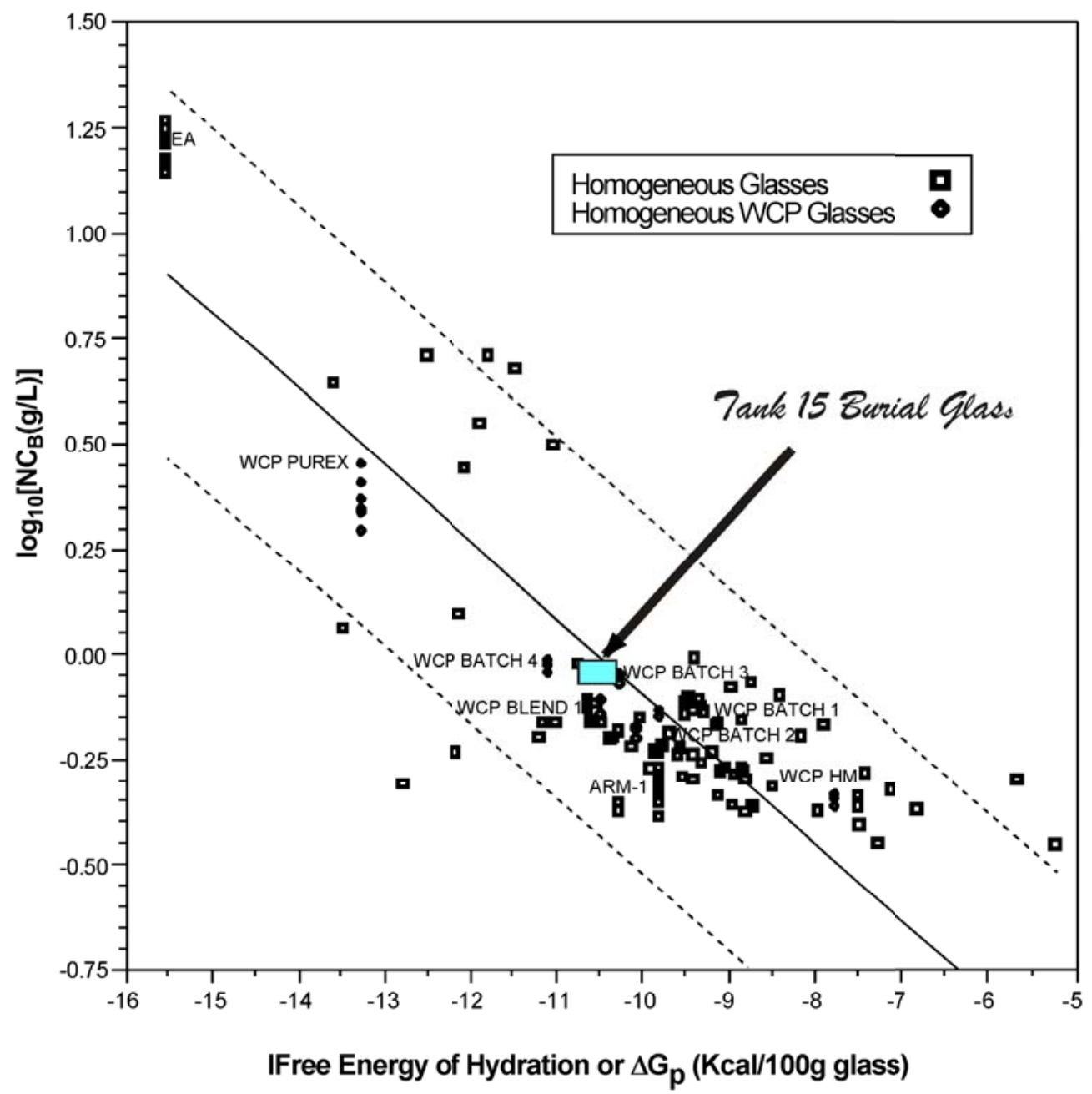

Figure 5. Performance of the SRNL Tank 15 burial glasses as measured by the short-term (7-day) Product Consistency Test and the THERMO ${ }^{\mathrm{TM}}$ model based on boron releases. $\left(\mathrm{NC}_{\mathrm{B}}\right.$ is the Normalized Release $\left(\mathrm{g}_{\text {wasteform }} / \mathrm{L}_{\text {leachate }}\right)$ as defined in $\mathrm{Eq}$. 1.) The Waste Compliance Plan (WCP) glasses shown on the figure are reference glasses that bracket the composition of the glasses intended to be processed in the SRS HLW melter. 


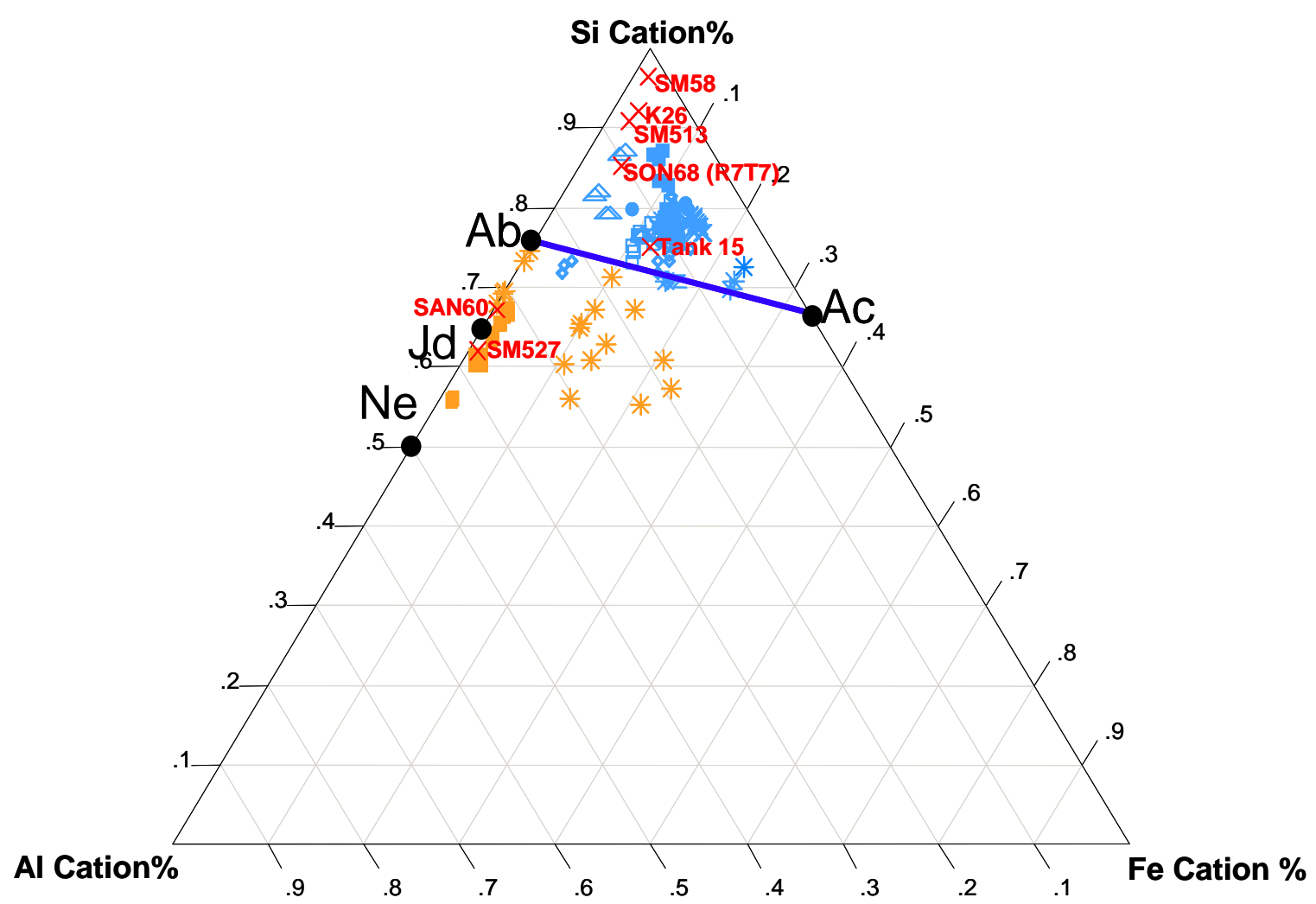

Figure 6. Predicted performance of the burial glasses in terms of the return to the forward rate. Glasses below the Albite (Ab)-Acmite (Ac) join are predicted to form analcime or paragaonite return to the forward rate (Stage III) while glasses above the Ab-Ac join are predicted to form nontronite clays and/or ferrite phases and leach at steady state (Stage II) rates. Note that the Canadian (CRNL) glasses are not included as they are not borosilicate glasses and this methodology has not been proven to apply to aluminosilicate glasses. 

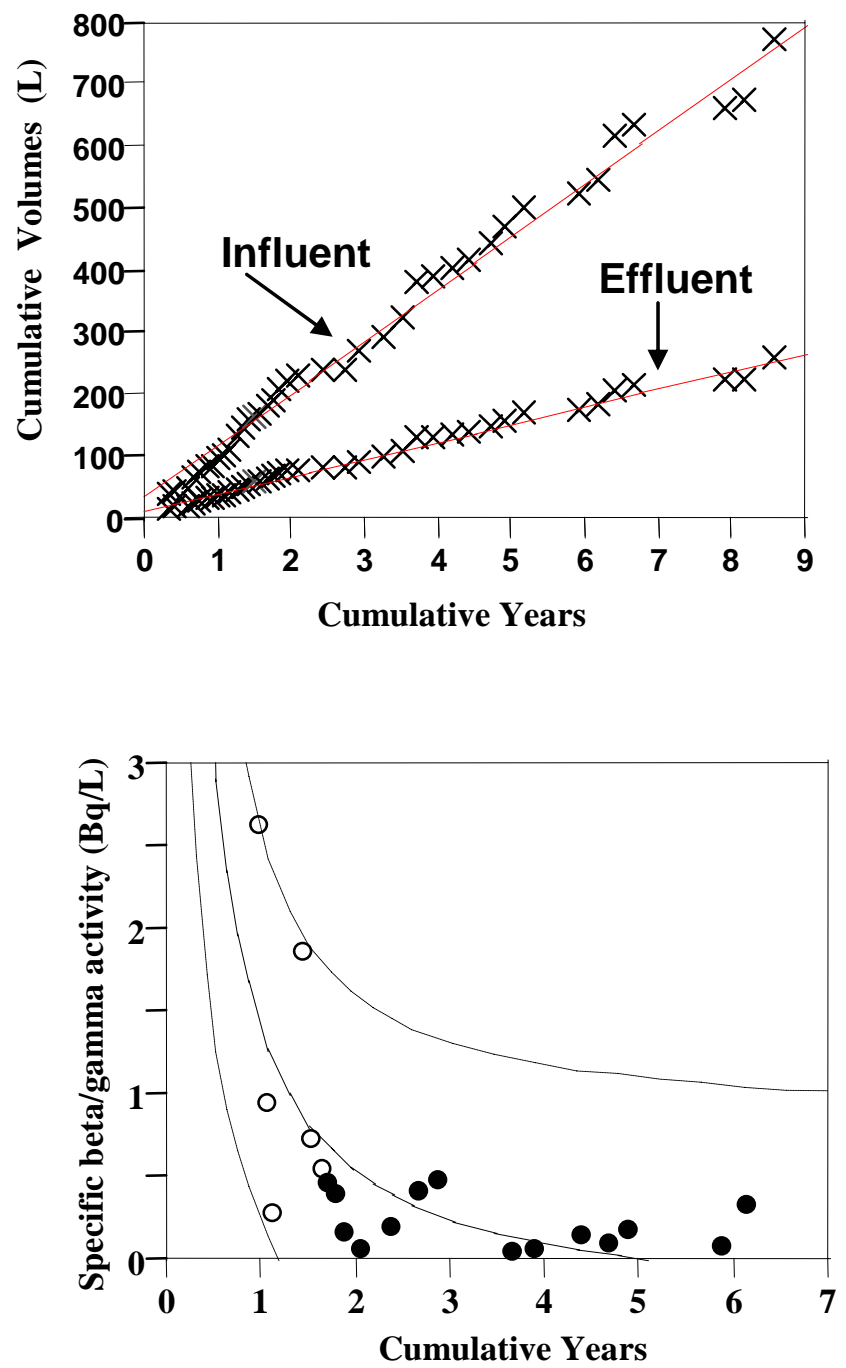

Figure 7. Cumulative groundwater volume that contacted the radioactive Tank 15 waste glass as a function of time (top) and the specific beta/gamma radioactivity of the groundwater as a function of time (bottom). Open circles represent monthly sampling intervals and solid circles represent quarterly sampling intervals. 

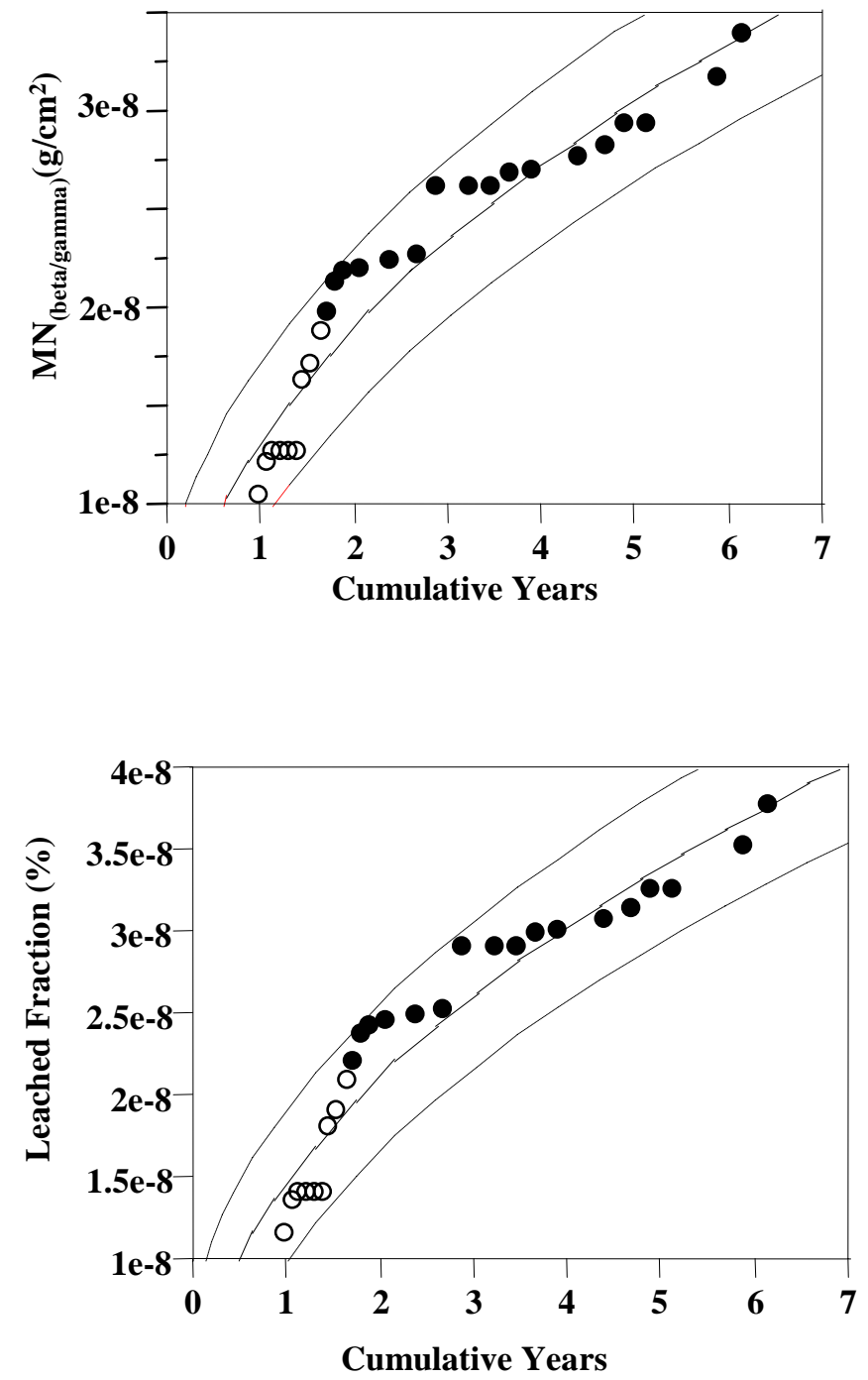

Figure 8. Normalized mass losses (top) and leached fraction of beta/gamma (bottom) from Tank 15 glass. Open circles represent monthly sampling intervals and solid circles represent quarterly sampling intervals. 

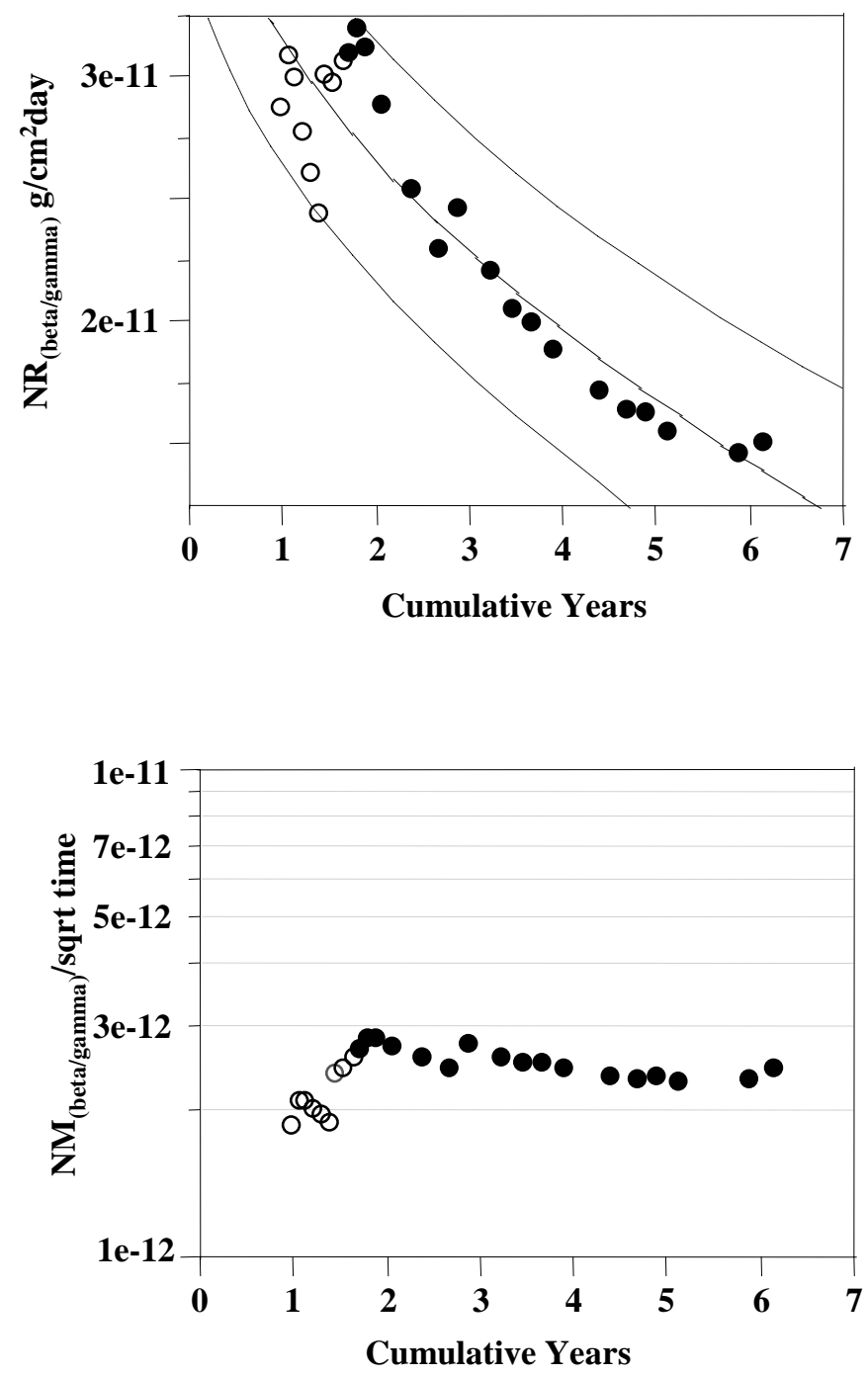

Figure 9. Average normalized leaching rates (top) based on $\beta / \delta$ and normalized mass loses divided by square root of time (bottom) for Tank 15 glass. Open circles represent monthly sampling intervals and solid circles represent quarterly sampling intervals. 


\section{REFERENCES}

$1 \quad$ P. Van Iseghem and B. Grambow, "The Long-Term Corrosion and Modeling of Two Simulated Belgian Reference High-Level Waste Glasses,” Sci. Basis for Nuclear Waste Management XI, J.J. Apted and R.E. Westerman (Eds.), Materials Research Society, Pittsburgh, PA, 631-639 (1987).

2 Y. Inagaki, K. Idemitsu, T. Arima, T. Maeda, H. Ogawa, F. Itonaga, “AlterationPhase Formation and Associated Cesium Release During Alteration of R7T7 Waste Glass,” Scientific Basis for Nuclear Waste Mgt. XXV, B.P. McGrail and G.A. Cragnoliono (Eds.), Materials Research Society, Pittsburgh, PA., 589-596 (2002).

3 T.A. Abrajano, J.K. Bates, and C.D. Byers, “Aqueous Corrosion of Natural Nuclear Waste Glasses. I. Comparative Rates of Hydration in Liquid and Vapor Environments at Elevated Temperatures,” J. Non-Cryst. Solids 84, 251-257 (1986).

4 G.G. Wicks, “US Field Testing Programs and Results,” J. of Nucl. Materials, 298, 78-85 (2001).

5 G.G. Wicks, “Nuclear Waste Glasses: Corrosion Behavior and Field Tests,” Corrosion of Glass, Ceramics, and Ceramic Superconductors, D.E. Clark and B.K. Zoitos, Noyes Publications, Park Ridge, NJ, 218-268 (1992).

6 P. Van Iseghem, “ In Situ Testing of Waste Glass in Clay,” Scientific Basis for Nuclear Waste Mgt. XVII, Mat. Res. Soc. Symp. Proc. Vol 333, 133-144 (1994).

$7 \quad$ A. Lodding and P. Van Iseghem, “In-depth Distributions of Elements in Leached Layers on Two HLW Waste Glasses After Burial in Clay; Step-scan by SIMS,” J. Nucl. Mat., 298, 197-202 (2001).

8 P. Van Iseghem, E. Valcke, and A. Lodding, "In Situ Testing of the Chemical Durability of Vitrified High-level Waste in a Boom Clay Formation in Belgium: Discussion of Recent Data and Concept of a New Test,” J. Nucl. Mat., 298, 86-94 (2001).

9 E. Valcke, S. Smets, S. Labat, K. Lemmens, P. Van Iseghem, P. Thomas, N. Godon, P. Jollivet, G. Parisot, J. Mestre, N. Jockwer, K. Wieczorek, and C. Pozo, “CORALUS: An Integrated In Situ Corrosion Test on $\alpha$-Active HLW Glass,” Scientific Basis for Nuclear Waste Mgt. XXIX, Mat. Res. Soc. Symp. Proc. Vol 932, 67-78 (2006).

10 E. Valcke, M. Gysemans, H. Moors, P. Van Iseghem, N. Godon, and P. Jollivet, "Leaching and Migration of Np, Pu, and Am from $\alpha$-doped SON68 HLW Glass in Contact with Dense Clay,” Scientific Basis for Nuclear Waste Mgt. XXIX, Mat. Res. Soc. Symp. Proc. Vol 932, 999-1006 (2006). 
11 W.F. Merritt, “The Leaching of Radioactivity from Highly Radioactive Glass Blocks Buried Below the Water Table: Fifteen Years of Results,” Atomic Energy of Canada Ltd Report No. AECL-5317, Ontario, Canada (1976).

12 A.R. Bancroft and J.D. Gamble, “Initiation of a Field Burial Test of the Disposal of Fission Products Incorporated into Glass,” Atomic Energy of Canada Ltd. Report No. AECL-718, Ontario, Canada (1978).

13 T.W. Melnyk, F.B. Walton, and L.H. Johnson, "High Level Waste Glass Field Burial Tests at CRNL: The Effect of Geochemical Kinetics on the Release and Migration of Fission Products in a Sandy Soil Aquifer,” Nuclear \& Chem. Waste Management, 5, 49-XX (1984).

14 J.C. Tait, W.H. Hocking, J.S. Betteridge, and G. Bart, "Field Burial Results and SIMS Analysis of the Chalk River Glass Blocks,” Advances in Ceramics, V.20: “Nuclear Waste Management II, Eds. D.E. Clark, W.B. White, and A.J. Machiels, American Ceramic Society, Columbus, OH, 559-565 (1986).

15 W.F. Merritt, “Permanent Disposal By Burial of Highly Radioactive Wastes Incorporated into Glass,” Proceedings of a Symposium on the Disposal of Radioactive Wastes into the Ground,” International Atomic Energy Agency (IAEA) May 29-June 2, 1967, 403-408 (1967).

16 M.I. Ojovan, N.V. Ojovan, I.V. Startceva, G.N. Chuikova, and A.S. Barinov, "Simulation of the Waste Glass Behavior in a Loamy Soil of the Wet Repository Site,” Mat. Res. Soc. Symp. Proc., V. 663, 837-842 (2001).

17 Ojovan, M.I., Lee, W.E., Barinov, A.S., Startceva, I.V., Bacon, D.H., McGrail, B.P., and Vienna, J.D., "Corrosion of Low Level Vitrified Radioactive Waste in a Loamy Soil,” Glass Technology, 47 [2] 48-55 (2006).

18 B.P. McGrail, D.H. Bacon, P.D. Meyer, M.I. Ojovan, D.M. Strachan, N.V. Ojovan, and I.V. Startceva, “New Developments in Field Studies of Low Activity Waste Glass Corrosion and Contaminant Transport,” Mat Res. Soc. Symp. Proc. V. 757, 83-95 (2003).

19 M.I. Ojovan, N.V. Ojovan, I.V. Startceva, G.N. Tchuikova, Z.I. Golubeva, and A.S. Barinov, "Waste Glass Behavior in a Loamy Soil of a Wet Repository Site,” Jour. Nucl. Mat., 298, 174-179 (2001).

20 M.I. Ojovan, R.J. Hand, N.V. Ojovan, and W.E. Lee, “Corrosion of Alkaliborosilicate Waste Glass in K-26 in Non-saturated Conditions,” Jour. Nucl. Mat., 340, 12-24 (2005). 
21 I.A. Sobolev, M.I. Ojovan, O.G. Batyukhnova, N.V. Ojovan, and T.D. Scherbatova, "Waste Glass Leaching and Alteration Under Conditions of Open Site Tests," Mat. Res. Soc. Symp., V. 465, 245-252 (1997).

22 N.V. Ojovan, I.V. Sartceva, A.S. Barinov, A.V. Mokhov, M.I. Ojovan, and G. Mobus, "Secondary Phases on the Surface of Real Vitrified Radioactive Waste Disposed in a Loamy Soil,” Mat. Res. Soc. Symp. Proc., V. 807, 139-144 (2004).

23 C.M. Jantzen, J.B. Pickett, K.G. Brown, T.B. Edwards, U.S. Patent \#5,846,278, “Method of Determining Glass Durability (THERMO' $\left.{ }^{\text {TM}}\right)$ " (December 8, 1998).

24 C.M. Jantzen, J.B. Pickett, K.G. Brown, T.B. Edwards, and D.C. Beam, "Process/Product Models for the Defense Waste Processing Facility (DWPF): Part I. Predicting Glass Durability from Composition Using a Thermodynamic Hydration Energy Reaction MOdel (THERMO),” US DOE Report WSRC-TR93-0672, 464p. (September, 1995).

25 C.M. Jantzen and K.G. Brown, "Impact of Phase Separation on Waste Glass Durability,” Environmental Issues and Waste Management Technologies in the Ceramic and Nuclear Industries, V, G. T. Chandler (Eds.), Ceramic Transactions, V. 107, 289-300 (2000).

26 ASTM C1285. "Standard Test Methods for Determining Chemical Durability of Nuclear, Hazardous, and Mixed Waste Glasses and Multiphase Glass Ceramics: The Product Consistency Test (PCT),” Annual Book of ASTM Standards, Vol. 12.01 (2002).

27 C.M. Jantzen and J.M. Pareizs, “Glass Durability Modeling: Application of Activated Complex Theory (ACT) for High Level Waste (HLW) Glass Melter Process Control,” WSRC-TR-2005-00317 (in revision for J. Nucl. Materials).

28 J.E. Mendel (Compiler), Final Report of the Defense High-Level Waste Leaching Mechanisms Program, US DOE Report PNL-5157, Battelle Pacific Northwest Laboratories, Richland WA (1984).

29 L.L.Hench and D.E. Clark, "Surface Properties and Performance Prediction of Alternative Waste Forms,” NUREG/CR-3472, Vol. 2 (1986).

30 R.W. Douglas and T.M.M. El-Shamy, "Reactions of Glasses with Aqueous Solutions,” J. Am. Ceram. Soc., 50[1], 1-8 (1967)

31 C.M. Jantzen, “Thermodynamic Approach to Glass Corrosion,” Corrosion of Glass, Ceramics, and Ceramic Superconductors, D.E. Clark and B.K. Zoitos, Noyes Publications, Park Ridge, NJ, 153-215 (1992). 
32 R.M. Wallace and G.G. Wicks, "Leaching Chemistry of Defense Borosilicate Glass,” Scientific Basis for Nuclear Waste Management, VI, D.G. Brookins (Ed.), Elsevier North Holland, New York, 23-28 (1983).

33 G.G. Wicks, W.C. Mosley, P.G. Whitkop, and K.A. Saturday, "Durability of Simulated Waste Glass-Effects of Pressure and Formation of Surface Layers,” J. Non-Cryst. Solids, $\underline{49}$, 413-28 (1982).

34 C.M. Jantzen, D.R. Clarke, P.E.D. Morgan, and A.B. Harker, "Leaching of Polyphase Nuclear Waste Ceramics: Microstructural and Phase Characterization,” J. Am. Ceram. Soc., 65[6]. 292-300 (1982).

35 A. Gauthier, P. LeCoustumer, and J-H. Thomassin, "Nature and Effect of the Alteration Layer During Nuclear Waste Glass Dissolution,” Scientific Basis for Nuclear Waste Mgt. XXV, B.P. McGrail and G.A. Cragnoliono (Eds.), Materials Research Society, Pittsburgh, PA., 555-561 (2002).

36 L.L. Hench and D.E. Clark, "Physical Chemistry of Glass Surfaces,” J. Non-Cryst. Solids, 28, 83-105 (1978).

37 A.B. Woodland, J.K. Bates, T.J. Gerding, "Parametric Effects on Glass Reaction in the Unsaturated Test Method,” U.S. DOE Report ANL-91/36, Argonne National Laboratory, Argonne, IL, 130pp (December, 1991).

38 J.K. Bates, C.R. Bradley, E.C. Buck, J.C. Cunnane, N.L. Dietz, W.L. Ebert, J.W. Emery, R.C. Ewing, X. Feng, T.J. Gerding, M. Gong, W.-T Han, J.C. Hoh, J.J. Mazer, M. Tomozawa, L.-M. Wang, and D.J. Wronkiewicz, “ANL Technical Support Program for DOE Environmental Restoration and Waste Management, Annual Report October 1990-September 1991,” US DOE Report ANL-92/9, Argonne National Laboratory, Argonne, IL, 149pp (March, 1992).

39 X. Feng, J.C. Cunnane, and J.K. Bates, “A Literature Review of Surface Alteration Layer Effects on Waste Glass Behavior,” Ceramic Transactions, V. 39 , G.B. Mellinger (Ed.), American Ceramic Society, Westerville, OH, 341-352 (1994).

40 A.K. Bandyopadhyai, R. Jabra, and J. Phalippou, "Association of OH Groups with Boron and Silicon Atoms in $\mathrm{SiO}_{2}-\mathrm{B}_{2} \mathrm{O}_{3}$ Glasses by Infrared Spectroscopy,” J. Mat. Sci. Letters, 8[12], 1464-1467 (1989).

41 R.J. Charles, “Static Fatigue of Glass, I and II,” J. of Applied Physics, 29 [11] 1549-1560 (1958).

42 J.K. Bates and L.J. Jardine, "Hydration Aging of Nuclear Waste Glass,” Science, 218, 51-52 (1982). 
43 F. C. Perez-Cardenas, Hao Gan, Xiaodong Lu, and I.L. Pegg, "Mechanism of Vapor Phase Hydration in High Sodium Waste Glasses from Computer Simulations,” Scientific Basis for Nuclear Waste Mgt. XXV, B.P. McGrail and G.A. Cragnoliono (Eds.), Materials Research Society, Pittsburgh, PA., 581-588 (2002).

44 W.L. Ebert, “The Effects of the Glass Surface Area/Solution Volume Ratio on Glass Corrosion: A Critical Review,” U.S. DOE Report ANL-94/34, Argonne National Laboratory, Argonne, IL, 289p (March 1995).

45 W.L. Ebert, E.C. Buck, J.S. Luo, S.W. Tam, and J.K. Bates, “Corrosion Behavior of Environmental Assessment Glass in Product Consistency Tests of Extended Duration,” U.S. DOE Report ANL-98/27, Argonne National Laboratory, Argonne, IL, 69p (September 1998).

46 X. Feng, J.C. Cunnane, and J.K. Bates, “A Literature Review of Surface Alteration Layer Effects on Waste Glass Behavior,” Ceramic Transactions, V. 39 , G.B. Mellinger (Ed.), American Ceramic Society, Westerville, OH, 341-352 (1994).

47 A.B. Woodland, J.K. Bates, T.J. Gerding, "Parametric Effects on Glass Reaction in the Unsaturated Test Method,” U.S. DOE Report ANL-91/36, Argonne National Laboratory, Argonne, IL, 130pp (December, 1991).

48 J.K. Bates, C.R. Bradley, E.C. Buck, J.C. Cunnane, N.L. Dietz, W.L. Ebert, J.W. Emery, R.C. Ewing, X. Feng, T.J. Gerding, M. Gong, W.-T Han, J.C. Hoh, J.J. Mazer, M. Tomozawa, L.-M. Wang, and D.J. Wronkiewicz,” ANL Technical Support Program for DOE Environmental Restoration and Waste Management, Annual Report October 1990-September 1991,” US DOE Report ANL-92/9, Argonne National Laboratory, Argonne, IL, 149pp (March, 1992).

49 D.J. Wronkiewicz, J.K. Bates, E.C. Buck, J.C. Hoh, J.W. Emery, and L.M. Wang, "Radiation Effects in Moist-Air Systems and the Influence of Radiolytic Product Formation on Nuclear Waste Glass Corrosion,” U.S. DOE Report ANL-97/15, Argonne National Laboratory, Argonne, IL (July, 1997).

50 E.C. Buck, J.A. Fortner, J.K. Bates, X. Feng, N.L. Dietz, C.R. Bradley, and B.S. Tani, “Analytical Electron Microscopy Examination of Solid Reaction Products in Long-Term Tests of SRL 200 Waste Glasses,” Scientific Basis for Nuclear Waste Mgt. XVII, A. Barkatt and R.A. VanKonynenburg (Eds), Materials Research Society, Pittsburgh, PA, 585-593 (1994).

51 J.S. Luo, T.A. Abrajano, Jr., and W.L. Ebert, “Natural Analogues of Nuclear Waste Glass Corrosion,” U.S. DOE Report ANL-98/22, Argonne National Laboratory, Argonne, IL (September, 1998). 
52 B.H.W. S. deJong, C.M. Schramm, and V.E. Parziale, “Polymerization of Silicate and Aluminate Tetrahedra in Glasses, Melts, and Aqueous Solutions, IV.

Aluminum Coordination in Glasses and Aqueous Solutions and Comments on the Aluminum Avoidance Principle,” Geochim. Cosmochim. Acta, 47, 1223-1236 (1983).

53 L.L. Ames and L.B. Sand, "Factors Effecting Maximum Hydrothermal Stability in Montmorillonites,” Am. Mineralogist, 43, 461-468 (1958).

54 R.Roy and L.B. Sand, “A Note on Some Properties of Synthetic Montmorillonites,” Am. Mineralogist, 41, 505-509 (1956).

55 R. Roy and E.F. Osborn, “The System $\mathbf{A l}_{2} \mathbf{O}_{3}-\mathbf{S i O}_{2}-\mathbf{H}_{2} \mathbf{O}$,” Am. Mineralogist, 39, 853-885 (1954).

56 R.A. Sheppard, “Zeolitic Diagenesis of Tuffs in the Miocene Chalk Hills Formation, Western Snake River Plain, Idaho,” U.S. Geological Survey Bulletin, 27p (1963).

57 B.H.W. S. deJong, C.M. Schramm, and V.E. Parziale, “Polymerization of Silicate and Aluminate Tetrahedra in Glasses, Melts, and Aqueous Solutions, IV. Aluminum Coordination in Glasses and Aqueous Solutions and Comments on the Aluminum Avoidance Principle,” Geochim. Cosmochim. Acta, 47, 1223-1236 (1983).

58 A.F. White, "Weathering Characteristics of Natural Glass and Influences on Associated Water Chemistry,” J. Non-Cryst. Solids, 67, 225-244 (1984)

59 R.A. Sheppard and A.J. Gude, "Distribution and Genesis of Authigenic Silicate Minerals in Tuffs of Pleistocene Lake Tecopa, Inyo County, California,” US Geol. Survey Prof. Paper 597, 38p. (1968)

60 D. Savage and N.A. Chapman, "Hydrothermal Behavior of Simulated Waste Glass- and Waste-Rock Interactions under Repository Conditions,” Chem. Geol., 36, 59-86 (1982).

61 J.K. Bates, C.R. Bradley, N.L. Dietz, W.L. Ebert, J.W. Emery, T.J. Gerding, J.C. Hoh, J.J. Mazer, and J.E. Young, “Unsaturated Glass Testing for DOE Program in Environmental Restoration and Waste Management, Annual Report, October 1989-September 1990,” U.S. DOE Report ANL-90/40, Argonne National Laboratory, Argonne, IL (1991).

62 M.E. Morgenstein and D.L. Shettel, Jr., "Evaluation of Borosilicate Glass as a High-Level Radioactive Waste Form,” High Level Radioactive Waste 
Management, Proc. Fourth Annual International Conf., Vol. 2, Am. Nuclear Soc, La Grange Park, IL, 1728-1734 (1993)

63 R.C. Ewing, “Natural Glasses: Analogues for Radioactive Waste Forms,” Scientific Basis for Nuclear Waste Management, I, G.J. McCarthy (Ed)., Plenum Press, New York, 57-68 (1979).

64 G. Malow, W. Lutze and R.C. Ewing, “Alteration Effects and Leach Rates of Basaltic Glasses: Implications for the Long-Term Stability of Nuclear Waste

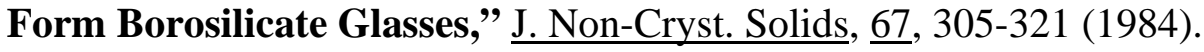

65 C.C. Allen, "Stability and Alteration of Naturally Occurring Low-Silica Glasses: Implications for the Long Term Stability of Waste Form Glasses,” Sci. Basis for Nuclear Waste Mgt. V, W. Lutze (Ed.), Elsevier Science Publ., New York, 37-44 (1982).

66 C.M. Jantzen and M.J. Plodinec, “Thermodynamic Model of Natural, Medieval, and Nuclear Waste Glass Durability,” J. Non-Crystalline Solids, 67, 207-233 (1984).

67 W.L. Bourcier, D.W. Peiffer, K.G. Knauss, K.D. McKeegan, and D.K. Smith, "Model for Borosilicate Glass Dissolution Based on Dissolution Affinity of a Surface Alteration Layer," Scientific Basis for Nuclear Waste Management, XIII, V.M. Oversby and P.W. Brown (Eds.) Materials Research Society, Pittsburgh, PA, Volume 176, 209-216 (1990).

68 Y. Inagaki, K. Idemitsu, T. Arima, T. Maeda, H. Ogawa, F. Itonaga, “AlterationPhase Formation and Associated Cesium Release During Alteration of R7T7 Waste Glass,” Scientific Basis for Nuclear Waste Mgt. XXV, B.P. McGrail and G.A. Cragnoliono (Eds.), Materials Research Society, Pittsburgh, PA., 589-596 (2002).

69 T.A. Abrajano, J.K. Bates, and C.D. Byers, “Aqueous Corrosion of Natural Nuclear Waste Glasses. I. Comparative Rates of Hydration in Liquid and Vapor Environments at Elevated Temperatures,” J. Non-Cryst. Solids 84, 251-257 (1986).

70 W.L. Ebert, J.K. Bates, C.R. Bradley, E.C. Buck, N.L. Dietz, and N.R. Brown, “The Long-Term Alteration of Borosilicate Waste Glasses,” Ceramic Transactions V.39, American Ceramic Society, Westerville, OH, 333-340 (1994).

71 D.H. Bacon, M.I. Ojovan, B.P. McGrain, N.V. Ojovan, and I.V. Startsceva, "Vitrified Waste Corrosion Rates from Field Experiment and Reeactive Transport Modeling," ICEM03-4509, Am. Soc. Met. Eng. (2003).

72 G.B. Woolsey, R.M. Galloway, M.J. Plodinec, E.L. Wilhite, and J.R. Fowler, “Processing of Tank 15 Sludge,” USDOE Report DPST-80-361 (June 1980). 
73 J.A. Stone, “Separation of SRP Waste Sludge and Supernate,” USDOE Report DP-1441 (November 1976).

74 Jantzen,C.M., Bibler, N.E., Beam, D.C. and Pickett, M.A., “Characterization of the Defense Waste Processing Facility (DWPF) Environmental Assessment (EA) Glass Standard Reference Material,” U.S. DOE Report WSRC-TR-92-346, Rev. 1, Westinghouse Savannah River Company, Aiken, SC (February 1993).

75 G.L. Smith, "Characterization of Analytical Reference Glass-1 (ARG-1)”, U.S. DOE Report PNL-8992, Pacific Northwest National Laboratory, Richland, WA, (1993).

76 B.P. McGrail, J.P. Icenhower, D.K. Shuh, P. Liu, J.G. Darab, D.R. Baer, S. Thevuthasen, V. Shutthanandan, M.H. Engelhard, C.H. Booth, P. Nachimuthu, "The Structure of $\mathrm{Na}_{2} \mathrm{O}-\mathrm{Al}_{2} \mathrm{O}_{3}-\mathrm{SiO}_{2}$ Glass: Impact on Sodium Ion Exhange in $\mathrm{H}_{2} \mathrm{O}$ and $\mathbf{D}_{\mathbf{2}} \mathbf{O}$,” J. Non-Cryst. Solids, 296, 10-26 (2001).

77 M.I. Ojovan, O.G. Batyukhova, S.A. Dmitriev, A.S. Barinov, and I.V. Startceva, “An Assessment of Radionuclide Release Inventory Based on Long-Term Field Tests of Nuclear Waste glass K-26,” ICEM05-1067 (2005).

78 C.M. Jantzen, C.M. and Brown, K.G., "Impact of Phase Separation on Waste Glass Durability,” Ceram. Trans., V. 107, 289-300 (2000).

79 D.K. Bailey and J.F. Schairer, "The System $\mathrm{Na}_{2} \mathbf{O}-\mathrm{Al}_{2} \mathbf{O}_{3}-\mathrm{Fe}_{2} \mathbf{O}_{3}-\mathrm{SiO}_{2}$ at $\mathbf{1}$ Atmosphere, and the Petrogenesis of Alkaline Rocks,” Journal of Petrology, 7[1], 114-170 (1966).

80 I. Hager, M. Hahnert, and W. Hinz, "Beitrag zur Phasentrennunung in Glasern der Systemme $\mathrm{Na}_{2} \mathrm{O}-\mathrm{SiO}_{2}-\mathrm{B}_{2} \mathrm{O}_{3}$ and $\mathrm{Na}_{2} \mathbf{O}-\mathrm{SiO}_{2}-\mathrm{Al}_{2} \mathrm{O}_{3}$," Silikatechnik, 18 [11], 360 (1967).

81 J.A. Topping and M.K. Murthy, "Effect of Small Additions of $\mathrm{Al}_{2} \mathrm{O}_{3}$ and $\mathrm{Ga}_{2} \mathbf{O}_{3}$ on the Immiscibility Temperature of $\mathbf{N a}_{2} \mathbf{O}-\mathbf{S i O}_{2}$ Glasses,” J. Am. Ceram. Soc., 56 [5], 270-275 (1973). 